\title{
Glacier mass balance over the central Nyainqentanglha Range during recent decades derived from remote-sensing data
}

\author{
KUNPENG WU, ${ }^{1-3 *}$ SHIYIN LIU, ${ }^{2,3} *$ ZONGLI JIANG, $^{4}$ JUNLI XU, ${ }^{5}$ ๑ JUNFENG WEI ${ }^{4}$
}

\author{
${ }^{1}$ School of Resources and Environment, Anqing Normal University, Anqing 246133, China \\ ${ }^{2}$ Institute of International Rivers and Eco-Security, Yunnan University, Kunming 650091, China \\ ${ }^{3}$ State Key Laboratory of Cryospheric Sciences, Northwest Institute of Eco-Environment and Resources, Chinese Academy \\ of Sciences, Lanzhou 730000, China \\ ${ }^{4}$ Department of Geography, Hunan University of Science and Technology, Xiangtan 411201, China \\ ${ }^{5}$ Department of Surveying and Mapping, Yancheng Teachers University, Yancheng 224007, China \\ Correspondence: Kunpeng Wu <wukunpeng2008@Izb.ac.cn>; Shiyin Liu <liusy@lzb.ac.cn>
}

\begin{abstract}
To obtain information on changes in glacier mass balance in the central Nyainqentanglha Range, a comprehensive study was carried out based on digital-elevation models derived from the 1968 topographic maps, the Shuttle Radar Topography Mission DEM (2000) and TerraSAR-X/ TanDEM-X (2013). Glacier area changes between 1968 and 2016 were derived from topographic maps and Landsat OLI images. This showed the area contained 715 glaciers, with an area of 1713.42 \pm $51.82 \mathrm{~km}^{2}$, in 2016 . Ice cover has been shrinking by $0.68 \pm 0.05 \% \mathrm{a}^{-1}$ since 1968. The glacier area covered by debris accounted for $\mathbf{1 1 . 9 \%}$ of the total and decreased in the SE-NW directions. Using digital elevation model differencing and differential synthetic aperture radar interferometry, a significant mass loss of $0.46 \pm 0.10 \mathrm{~m}$ w.e. $\mathrm{a}^{-1}$ has been recorded since 1968; mass losses accelerated from $0.42 \pm$ $0.20 \mathrm{~m}$ w.e. $\mathrm{a}^{-1}$ to $0.60 \pm 0.20 \mathrm{~m}$ w.e. $\mathrm{a}^{-1}$ between $1968-2000$ and 2000-2013, with thinning noticeably greater on the debris-covered ice than the clean ice. Surface-elevation changes can be influenced by ice cliffs, as well as debris cover and land- or lake-terminating glaciers. Changes showed spatial and temporal heterogeneity and a substantial correlation with climate warming and decreased precipitation.
\end{abstract}

KEYWORDS: debris-covered glaciers, glacier delineation, glacier mass balance, remote sensing

\section{INTRODUCTION}

The Tibetan Plateau (TP), known as the roof of the world or Third Pole, contains the largest concentration of glaciers and icefields outside the polar regions (Yao and others, 2008). Meltwater from these feeds the headwaters of many prominent Asian rivers (e.g. the Yellow, Yangtze, Mekong, Salween, Brahmaputra, Ganges and Indus) (Immerzeel and others, 2010), and are a key component of the cryospheric system (Li and others, 2008). Glaciers are important climate indicators because their extent and thickness adjust in response to climate change (Oerlemans, 1994; Yao and others, 2012). With a warming climate, many mountain glaciers have shrunk progressively in mass and extent during the past few decades (IPCC, 2013). However, slight mass gains or balanced mass budgets have been evident for parts of the central Karakoram, eastern Pamir and the western TP in recent years (Gardelle and others, 2012b, 2013; Yao and others, 2012; Neckel and others, 2014; Bao and others, 2015; Kääb and others, 2015; Ke and others, 2015). The relationships between glacier mass balance and climate change, water supply and the risk of glacier-related disasters, are the subject of much current research.

It is difficult to carry out in situ observations on the TP due to its rugged terrain and the great labor and logistical costs. Only 15 glaciers have decades of traditional mass-balance measurements (Yao and others, 2012). By comparing elevation data from more than two points in time, glacier height and volume changes can be determined and hence glacier * These authors contributed equally to this work and should be considered co-first authors. mass balance, after consideration of ice/firn/snow densities (Bolch and others, 2011; Kääb and others, 2012; Gardelle and others, 2013; Pieczonka and others, 2013; Shangguan and others, 2014; Paul and others, 2015; Brun and others, 2017; Zhou and others, 2018).

Glaciers in south-eastern Tibet are classified as temperate (maritime) type and are influenced by the South Asian monsoon (Li and others, 1986; Shi and Liu, 2000). Based on inventories from maps and remote sensing, or field measurements, a substantial reduction in glacier area and length has been recorded in this region from 1980 to 2013, as well as a glacier mass deficit from 2005 to 2009 (Yang and others, 2008, 2010; Yao and others, 2012; Li and others, 2014). Most previous studies used satellite laser altimetry or stereo photogrammetry to calculate the glacier height changes that determined pronounced negative glacier mass balances in the region (Gardelle and others, 2013; Gardner and others, 2013; Neckel and others, 2014; Kääb and others, 2015), although the results did differ slightly from each other. Laser altimetry from the ICESat (Ice, Cloud and Land Elevation Satellite) showed geodetic glacier-elevation difference trends in south-eastern Tibet during 2003-2008 of $-1.34 \pm 0.29 \mathrm{~m} \mathrm{a}^{-1}$ (Kääb and others, 2015), $-0.81 \pm 0.32$ $\mathrm{m} \mathrm{a}^{-1}$ (Neckel and others, 2014) and $-0.30 \pm 0.13 \mathrm{~m} \mathrm{a}^{-1}$ (Gardner and others, 2013), respectively. The large orbital gaps in ICESat footprint data mean spatial details cannot be mapped at a fine scale. A comparison between ASTER images found a mean glacier mass balance of $-0.62 \pm 0.23$ $\mathrm{m}$ w.e. $\mathrm{a}^{-1}$ in Nyainqentanglha from 2000 to 2016 (Brun and others, 2017). 
While stereo photogrammetry provides high resolution details on glacier height changes, it can be limited by image saturation, particularly at high elevations. Furthermore, the lack of local mass-balance measurements prevents analysis of glacier responses to climate change in the central Nyainqentanglha Range (CNR). Based on the Shuttle Radar Topography Mission (SRTM) and an interferometrically derived TanDEM-X elevation model, glaciers were determined to have experienced strong surface lowering in the CNR, at an average rate of $-0.83 \pm 0.57 \mathrm{~m} \mathrm{a}^{-1}$ from 2000 to 2014 (Neckel and others, 2017). While this pronounced surface-lowering value came from five debris-covered valley glaciers which are located in the east of the study area, it does not represent large scale glacier response to climate warming. For the climate background, most meteorological stations, located in inhabited river valleys, are far from the glacierized highmountain regions so their records cannot be used directly as climate background for them. Even in the same climate environment, glacier responses may differ due to local parameters, such as aspect, topography and debris cover (Kääb, 2005; Scherler and others, 2011; Neckel and others, 2017).

This study calculates geodetic glacier mass balances for a large number of glaciers in the CNR. Most glaciers have been mapped from aerial photographs taken in October 1980 and subsequently by SAR Interferometry (InSAR) in February 2000 (during the SRTM), resulting in a digital elevation model (DEM). Single-pass X-band InSAR from TerraSAR-X and TanDEM-X digital elevation measurements provided the basis for another map (Krieger and others, 2007). Bistatic Differential Synthetic Aperture Radar Interferometry (DInSAR) and common DEM differencing were used to estimate the geodetic glacier mass balance in different subregions of the CNR between 1968 and 2013.

\section{STUDY REGION}

The CNR $\left(30^{\circ} 9^{\prime}-30^{\circ} 53^{\prime} \mathrm{N}, 9^{\circ} 0^{\prime}-95^{\circ} 30^{\prime} \mathrm{E}\right)$ lies in southeastern Tibet, north of Linzhi County, east of Jiali County and west of Bomi County, and extends $\sim 130 \mathrm{~km}$ from west to east. South of this region is the Yigong Tsangpo River, a tributary of the Purlung Tsangpo River and a secondary tributary of the Yarlung Tsangpo River (Fig. 1). The elevation differences between mountain peaks and valley bottoms often reach $3000-3500 \mathrm{~m}$. The rugged topography with steep valleys and slopes results from the interplay of a still ongoing tectonic uplift and erosion ( $\mathrm{Li}$ and others, 1986). High precipitation amounts during the summer monsoon season (May to September) are the main reason for the intense erosion. The CNR is characterized by a strong climatic influence of the South Asian monsoon entering through the Yarlung Tsangpo valley (Loibl and others, 2014). More than $80 \%$ of annual precipitation falls from June to September, while winter months are characterized by cold and dry conditions (Molnar and others, 2010). According to the climatic classification of local meteorological station data, the CNR marks a transition zone between warm-wet subtropical and cold-dry plateau conditions (Leber and others, 1995). Previous studies showed that average annual precipitation in most high-elevation areas in the CNR exceeds $2000 \mathrm{~mm}$ (Shi and others, 1988). Farther north, the east-west orientation of the mountain range acts as a topographic barriers that produces heavy orographic rainfalls (Böhner, 2006; Maussion and others, 2014). This results in a distinct precipitation gradient that decreases from south to north (Shi and others, 1988).

The first Chinese Glacier Inventory (CGI) determined that glaciers covered $2537.7 \mathrm{~km}^{2}$ of our study region, with an estimated total volume of $454.2 \mathrm{~km}^{3}$ in $1968(\mathrm{Pu}, 2001$; Mi and others, 2002). At this time, $\sim 8 \%$ of the glacier area was covered by debris. Three glaciers in the CNR are larger than $100 \mathrm{~km}^{2}$, the Xiaqu (CGI code: 5O281B0702), Kyagqen (CGI code: 5O281B0729) and Nalong (CGI code: 5O281B0768). The Kyagqen, on the south slope of the CNR, $35.3 \mathrm{~km}$ long and $206.7 \mathrm{~km}^{2}$, with a terminus at $2900 \mathrm{~m}$ a.s.l., is the largest of these (Li and others, 1986). Above $4000 \mathrm{~m}$ a.s.l. it has a broad basin in which several ice streams converge to form a large accumulation zone. Below this, the glacier enters a narrow ice-filled valley where its velocity increases, and the tongue is $1000 \mathrm{~m}$ wide and $17 \mathrm{~km}$ long. The glacier terminus extends to subtropical conditions at an elevation of $2900 \mathrm{~m}$ a.s.l. (Li and others, 1986).

\section{DATA AND METHODS}

\subsection{Data}

Our study uses eight topographic maps at a scale of $1: 100000$ (Fig. 1 and Table 1). They were compiled by the Chinese Military Geodetic Service from airborne photos acquired in April 1968. Their geographic projection was based on the Beijing Geodetic Coordinate System 1954 (BJ54) geoid and the Yellow Sea 1956 datum. Using national trigonometric reference points, these maps were re-projected into the World Geodetic System 1984 (WGS1984)/Earth Gravity Model 1996 (EGM96) (Xu and others, 2013). The contours were digitized from topographic maps manually, and then using the Thiessen polygon method, converted into a raster DEM with a $30 \mathrm{~m}$ gridcell (hereafter called TOPO DEM) (Shangguan and others, 2010; Wei and others, 2015; Zhang and others, 2016). According to the national photogrammetric standard of China (Chinese National Standard, 2008), the nominal vertical accuracies of these topographic maps were $\pm 3.0, \pm 5.0$, \pm 8.0 and $\pm 14.0 \mathrm{~m}$ for the flat areas (with slopes $<2^{\circ}$ ), hilly areas (with slope $2-6^{\circ}$ ), mountain areas (with slope $6-25^{\circ}$ ) and high-mountain areas (with slope $>25^{\circ}$ ), respectively. The vertical accuracy of the TOPO DEM is better than $11 \mathrm{~m}$ on glaciers with mean slopes $<24^{\circ}$ which is common for most of the glacierized areas in the CNR.

Acquired by radar interferometry with C-band and X-band in early February 2000, the SRTM DEM can be referred to the glacier surface in the last balance year (1999) with slight seasonal variances (Zwally and others, 2011; Gardelle and others, 2013; Pieczonka and others, 2013). Due to large data gaps in the X-band DEM (Rabus and others, 2003), only $20 \%$ of the CNR glaciers are covered. Hence, the 1 arc-second SRTM C-band DEM was used in this study for glacier surface elevation change. The non-void-filled SRTM C-band DEM, with a swath width of $225 \mathrm{~km}$ and 1 arcsecond $(\sim 30 \mathrm{~m})$ resolution in WGS84/EGM96, is freely available on http://earthexplorer.usgs.gov/.

TerraSAR-X was launched in June 2007, and then its twin satellite, TanDEM-X was launched in June 2010 by the German Aerospace Center (DLR). Flying in close orbit formation, the two satellites act as a flexible single-pass SAR 


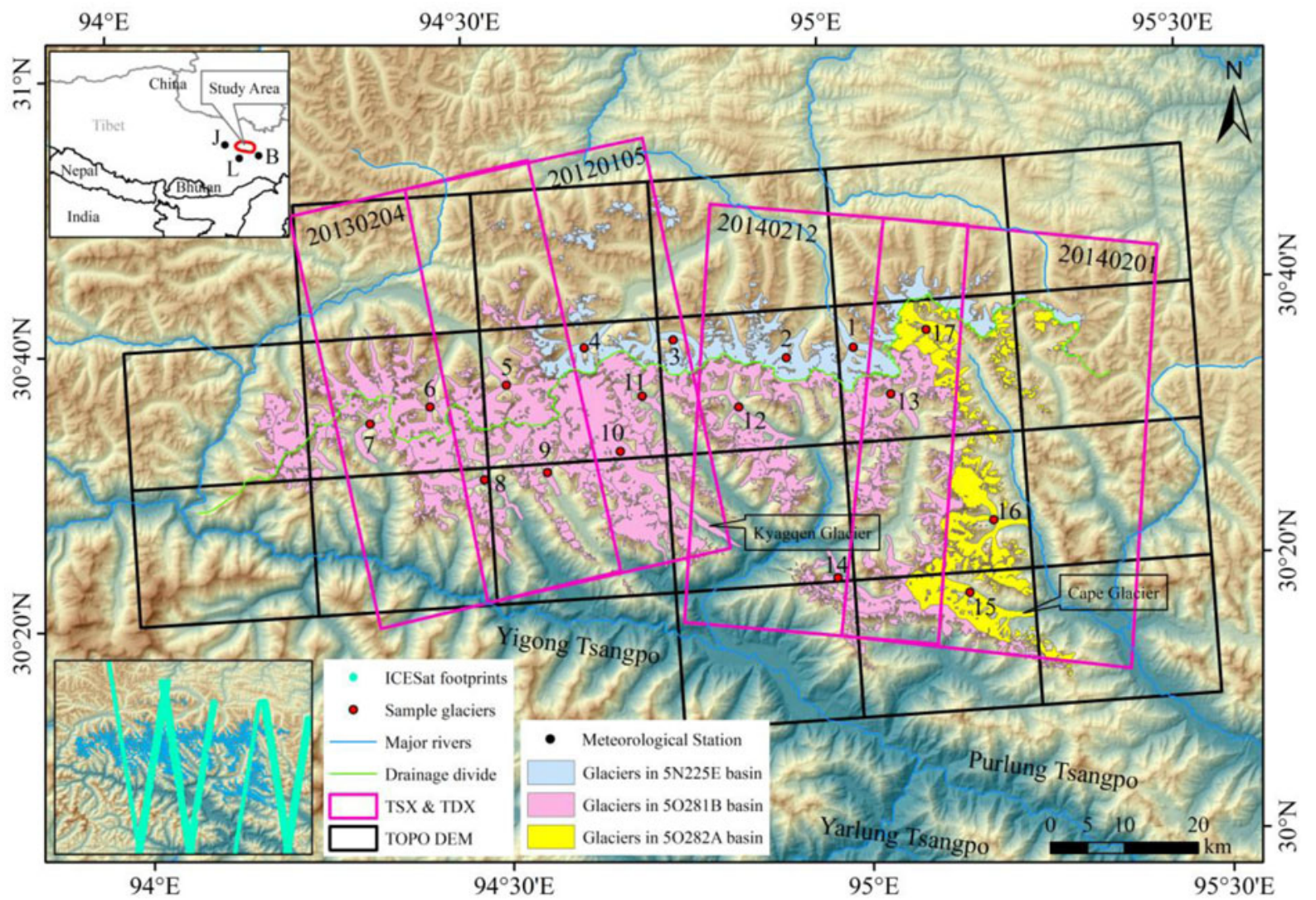

Fig. 1. Study area and distribution of 2016 glacier outlines in different drainage basins, and the location of the meteorological stations (J: Jiali station, L: Linzhi station, B: Bomi station). TOPO DEMs, TSX/TDX acquisitions and ICESat footprints. Numbers indicate specific sample glaciers chosen for analysis. The background map is SRTM DEM.

interferometer (Krieger and others, 2007). Four pairs of Xband bistatic TerraSAR-X/TanDEM-X data acquisitions in the experimental Co-registered Single look Slant range Complex (CoSSC) format, acquired in bistatic InSAR stripmap mode, were used in this study (Fig. 1, Tables 1,2). The frame sizes of these images were $\sim 40 \times 60 \mathrm{~km}$, with resolutions of $\sim 2.5 \mathrm{~m}$ in both the ground range and azimuth direction. To avoid seasonal variations induced by melting and snow cover, images were chosen mainly from those taken in February or adjacent months, the same season that the SRTM data were acquired.
Current glacier outlines were generated from Landsat imagery. Due to the influence of the South Asian monsoon, the CNR is almost permanently covered by snow and ice during summer months. The Operational Land Imager (OLI) sensor, on board Landsat-8, provides an excellent mid-resolution image source for compiling regional-scale glacier inventories and can provide good-quality multispectral images. Acquired from the United States Geological Survey (USGS), the Landsat OLI images are orthorectified with the SRTM DEM. We selected two Landsat OLI scenes from July and August 2016 as references for glacier area.

Table 1. Overview of satellite images and data sources

\begin{tabular}{|c|c|c|c|c|}
\hline Date & Source & ID & $\begin{array}{l}\text { Pixel } \\
\text { size m }\end{array}$ & Utilization \\
\hline Apr 1968 & $\begin{array}{l}\text { Topographic } \\
\text { Maps/TOPO } \\
\text { DEM }\end{array}$ & $\begin{array}{l}\text { H46E008018/H46E008019/H46E008020 H46E008021/ } \\
\text { H46E008022/H46E009017 H46E009018/H46E009019/ } \\
\text { H46E009020 H46E009021/H46E009022/H46E010017 } \\
\text { H46E010018/H46E010019/H46E010020 H46E010021/ } \\
\text { H46E010022 H46E011020 H46E011021/H46E011022 }\end{array}$ & $12 / 30$ & $\begin{array}{l}\text { Glacier delineation for } \\
1968 \text { and estimation of } \\
\text { glacier elevation change }\end{array}$ \\
\hline 11-22 Feb 2000 & SRTM C-band & - & 30 & $\begin{array}{l}\text { Estimation of glacier eleva- } \\
\text { tion change }\end{array}$ \\
\hline 4 Aug 201320 & Landsat OLI & LC81350392013216LGN00 & 15 & Glacier delineation for \\
\hline Oct 201527 Jul & Landsat OLI & LC81360392015293LGN00 & 15 & 2016 \\
\hline 201619 Aug & Landsat OLI & LC81350392016209LGN00 & 15 & \\
\hline 2016 & Landsat OLI & LC81360392016232LGN00 & 15 & \\
\hline 5 Jan 20124 Feb & TSX/TDX & 20120105T114457_20120105T114505 & 12 & Estimation of glacier eleva- \\
\hline 20131 Feb & TSX/TDX & 20130204T114501_20130204T114509 & 12 & tion change \\
\hline 2014 & TSX/TDX & 20140212T233757_20140212T233805 & 12 & \\
\hline
\end{tabular}


Table 2. Specification of the bistatic TSX/TDX SAR dataset used

\begin{tabular}{|c|c|c|c|c|c|c|}
\hline Date & Relative orbit & Orbital pass & Effective perpendicular baseline $\mathrm{m}$ & Height of ambiguity $\mathrm{m}$ & $\begin{array}{c}\text { Average incidence } \\
\text { angle }\end{array}$ & $\begin{array}{l}\text { Master } \\
\text { satellite }\end{array}$ \\
\hline 5 Jan 2012 & 67 & Ascending & 94.5 & 88.2 & 47 & TSX \\
\hline 4 Feb 2013 & 67 & Ascending & 126.0 & -64.4 & 45 & TSX \\
\hline 1 Feb 2014 & 59 & Descending & 122.0 & 63.3 & 44 & TSX \\
\hline $\begin{array}{c}12 \text { Feb } \\
2014\end{array}$ & 59 & Descending & 121.2 & 67.1 & 46 & TSX \\
\hline
\end{tabular}

\subsection{Glacier delineation}

Glacier outlines in 2016 were delineated using a band ratio method, a division of the visible or near-infrared band and shortwave infrared band of Landsat OLI images (Paul and others, 2009; Racoviteanu and others, 2009). A $3 \times 3$ median filter was applied to eliminate isolated ice patches $<0.01 \mathrm{~km}^{2}$ (Bolch and others, 2010b; Wu and others, 2016). In order to discriminate proglacial lakes, seasonal snow, supraglacial boulders and debris-covered ice, Landsat scenes without snow or cloud-free scenes acquired at nearly the same time, were used for reference when making manual adjustments. Generated from the SRTM-C DEM automatically, topographical ridgelines were used to divide the final contiguous ice coverage into individual glacier polygons (Guo and others, 2015).

Glaciers in the CNR in 1968 were inventoried (the first CGI) based on topographical maps with a scale of $1: 100000$. However, data from this inventory cannot be applied to derive glacier changes compared with glacier outlines in 2016 directly. The outlines of the first CGI were digitized manually based on scanned and well-georeferenced topographical maps, and validated with reference to the original aerial photographs. The spatial resolution of scanned topographical maps is $9 \mathrm{~m}$ for maps at a scale of $1: 100000$. They were first georeferenced to Geodetic Coordinate System (BJ54) geoid (datum level is Yellow Sea mean sea level at Qingdao Tidal Observatory in 1956) and then reprojected into World Geodetic System 1984 (WGS84)/Earth Gravity Model 1996 (EGM96) using national trigonometric reference points over the $\mathrm{CNR}$.

Uncertainty in the glacier outlines arises from positional and processing errors associated with glacier delineation (Racoviteanu and others, 2008; Bolch and others, 2010a). No distinct horizontal shift was observed in Landsat images and the impact of seasonal snow, cloud and debris cover was reduced by manual inspection and corrections (Bolch and others, 2010a; Guo and others, 2015). Comparing glacier outlines derived from Landsat-images with real-time kinematic differential GPS (RTK-DGPS) measurements, average offsets of \pm 10 and $\pm 30 \mathrm{~m}$ were acquired for the delineation of clean and debris-covered ice (Guo and others, 2015), whereas average offsets between topographic-maps outlines and Corona imagery were previously found to be $\pm 6.8 \mathrm{~m}(\mathrm{Wu}$ and others, 2016). On the basis of these average offsets, mean relative errors of \pm 0.8 and $\pm 3.0 \%$ were determined for glacier areas in 1968 and 2016, respectively.

\subsection{Glacier elevation changes}

Four acquisitions of bistatic TerraSAR-X/TanDEM-X images in the CoSSC format in both orbital passes were used to derive the decadal glacier height changes. Bistatic interferograms contain both flat earth and topographic phases from which glacier-elevation changes can be derived (Neckel and others, 2013; Paul and others, 2015; Li and Lin, 2017; $\mathrm{Li}$ and others, 2018). Two methods can be used: the first, based on DInSAR, uses orbital information from bistatic SAR images and reference DEMs (here SRTM DEM and TOPO DEM) to simulate the flat earth and topographic phases, and then removes them from the original bistatic interferogram to leave a differential interferogram. The second, common DEM differencing, generates a new DEM from bistatic SAR images, based on InSAR technology, and then performs common DEM differencing with respect to reference DEMs (Neckel and others, 2013). In the DInSAR method, most parts of the topographic phase have been simulated and removed and the reliability of phase unwrapping increased by the smaller phase gradients (Neckel and others, 2013), so the topographic residual phase can be transformed directly to an elevation change. In this study, the DInSAR method was used to detect glacier-elevation changes in the CNR from 1968 to 2013, and from 2000 to 2013.

To improve the phase-unwrapping procedure and minimize errors, the unfilled finished SRTM C-band DEM was employed. The use of the DInSAR method to acquire elevation changes from bistatic SAR images can be described by

$$
\begin{aligned}
\Delta \varphi_{\text {elevation }} & =-\frac{2 \pi B_{\perp} h}{\lambda R \sin \theta} \\
& =-\left(\frac{2 \pi B_{\perp} \Delta h_{\text {srtm }}}{\lambda R \sin \theta}+\frac{2 \pi B_{\perp} \Delta h_{\text {residual }}}{\lambda R \sin \theta}\right)
\end{aligned}
$$

where $\Delta \varphi_{\text {elevation }}$ is the elevation change, $B_{\perp}$ is the perpendicular baseline, $\lambda$ is the wavelength of the radar signal, $R$ is the geometric distance from the satellite to the scatterer, $\theta$ is the incidence angle and $h$ is the elevation, which can be split into elevation in SRTM C-band DEM $\left(\Delta h_{\text {srtm }}\right)$ and the elevation changes $\left(\Delta h_{\text {residual }}\right)$ due to glacier thinning or thickening (Kubanek and others, 2015; Li and others, 2018).

It is assumed that no height change occurs in the offglacier regions. Precise horizontal offset registration between the SRTM C-band DEM and the TerraSAR-X/ TanDEM-X acquisitions is mandatory. An initial lookup table was calculated, based on the relationship between the map coordinates of the SRTM C-band DEM segment covering the TerraSAR-X/TanDEM-X master file and the SAR geometry of the respective master file. Due to the sidelooking geometry of TerraSAR-X/TanDEM-X, distortion in the foreshortening, layover and shadow regions can result in some errors. Regions with severe foreshortening, layover and shadow were masked out. The horizontal offsets between both datasets were calculated by GAMMA's offset_pwrm module for cross-correlation optimization of the 
simulated SAR images. The horizontal registration and geocoding lookup table was refined with these offsets and used to translate the SRTM C-band DEM from geographic into SAR coordinates. A differential interferogram was then generated from the TerraSAR-X/TanDEM-X interferogram and the simulated phase of the co-registered SRTM C-band DEM. This was filtered by an adaptive filtering approach and the flattened differential interferogram unwrapped with GAMMA's minimum cost flow algorithm. The unwrapped differential phase could be transformed to absolute elevation changes from the computed phase-to-height sensitivity and select ground control points (GCPs) of the off-glacier regions of the SRTM C-band DEM.

In the interferometric processing of the TerraSAR-X/ TanDEM-X DEM, an artificial linear phase ramp was observed, which presumably related to an inaccurate flat earth estimate. This linear phase ramp was minimized by an additional baseline refinement based on off-glacier phase value from the differential interferogram. However, the baseline refinement cannot completely eliminate error, so a residual exists in the unwrapped differential interferogram. This residual can be regarded as a linear trend of elevation difference estimated by a 2-D first-order polynomial fit in off-glacier regions. The linear trend of elevation difference and a constant vertical offset were removed from maps of absolute elevation changes. Finally, the resulting datasets were translated from SAR coordinates into WGS84/EGM96 using the refined geocoding lookup table (Paul and others, 2015). In order to generate absolute elevation maps, the absolute elevation changes were added to the co-registered SRTM C-band DEM, and the optimized DEM was obtained in the first iteration. Then the optimized DEM was used to simulate topographic phase, calculate offset and difference with TerraSAR-X/TanDEM-X DEM (repeating the steps mentioned above), and the second elevation changes were obtained. The second elevation changes were added to the optimized DEM, and the optimized absolute DEM was obtained in the second iteration.

DEM differencing with the TOPO DEM and SRTM C-band DEM was employed to acquire the glacier-elevation change from 1968 to 2000 (Nuth and Kääb, 2011; Pieczonka and others, 2013; Wei and others, 2015; Liu and others, 2017). Based on the relationship between elevation difference, slope and aspect, relative horizontal and vertical distortions between the two datasets were corrected statistically (Nuth and Kääb, 2011). At first, a difference map was constructed with the TOPO DEM and SRTM C-band DEM. Before adjustments, the mean elevation difference for off-glacier regions was $6.73 \mathrm{~m}$. Outliers are usually found around data gaps and near DEM edges and were excluded using 5 and 95\% quantile thresholds based on statistical analysis (Pieczonka and others, 2013). Then, based on the cosinusoidal relationship between standardized vertical bias and topographical parameters (slope and aspect), the vertical biases and horizontal displacements were rectified simultaneously (Fig. 2). The biases, caused by different spatial resolutions between the two datasets, were refined using the relationship between elevation differences and maximum curvatures for both on- and off-glacier regions (Gardelle and others, 2012a). After these adjustments, the elevation differences in off-glacier regions were concentrated on the mean elevation difference at $-1.24 \mathrm{~m}$. It was concluded that elevation differences in the off-glacier regions had stabilized after these refinements making the processed DEMs suitable for estimating changes in the glaciers' mass balance.

A difference map between SRTM and TerraSAR-X/ TanDEM-X DEM was constructed by common DEM differencing. Based on the cosinusoidal relationship between elevation difference, slope and aspect, the vertical biases and horizontal displacements were rectified. Because TerraSARX/TanDEM-X DEM was created by the DInSAR method to optimize SRTM, both DEMs feature the same grid posting and are horizontally aligned. After these adjustments, the mean elevation difference in off-glacier regions was $0.80 \mathrm{~m}$, which is slightly larger than $0.79 \mathrm{~m}$ that estimated by the DInSAR method.

\subsection{Penetration depth}

When the SRTM DEM is used for geodetic mass-balance calculations, the penetration depth of the radar signal into snow and ice has to be considered (Rignot and others, 2001; Berthier and others, 2006; Gardelle and others, 2012a; Vijay and others, 2016; Neelmeijer and others, 2017). Previous studies have indicated that the penetration depth is affected by the carrier frequency, the density of snow
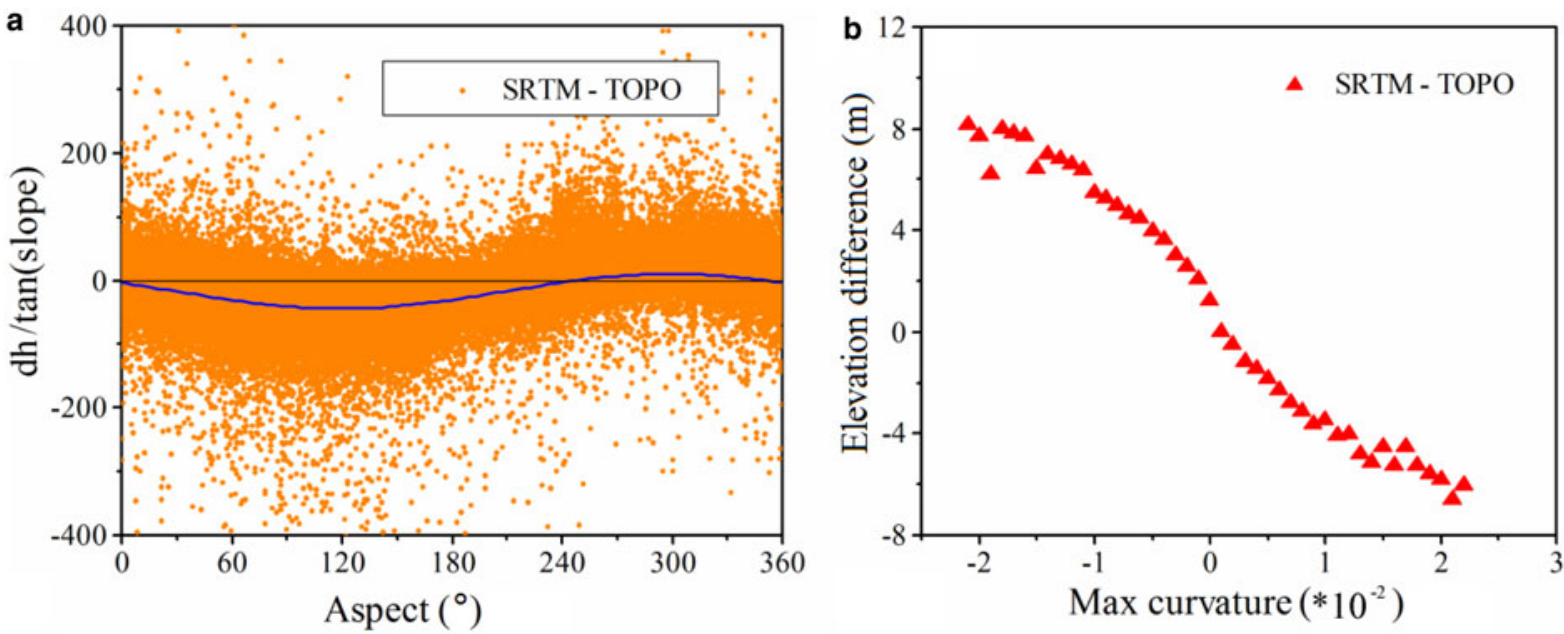

Fig. 2. Scatterplots of (a) aspect vs slope standardized elevation differences and (b) maximum curvature vs elevation difference in the CNR. 
and ice and its water content (Berthier and others, 2006; Kääb and others, 2015). Given that the TerraSAR-X/ TanDEM-X were observed mostly in February, when the SRTM was performed, and the carrier frequencies of the TerraSAR-X/TanDEM-X and the SRTM X-band satellites are almost the same, it is assumed that penetration depths will be similar between these two datasets and can be neglected (Li and Lin, 2017). As a first approximation, because the penetration depth of the SRTM X-band radar beam is much smaller than the C-band, the elevation difference between SRTM C-band and X-band DEMs on glacier can be considered to be the SRTM C-band radar beam penetration into snow and ice (Gardelle and others, 2012a). As the acquisition date of SRTM avoided the main rainy season (Yang and others, 2013), the penetration of radar signal would not occur in off-glacier regions, so elevation differences between SRTM C-band and X-band DEMs could be evaluated with common DEM differencing. At first, a difference map was constructed with SRTM C-band and X-band DEMs. Before adjustments, outliers are excluded using 5 and $95 \%$ quantile thresholds based on statistical analysis. Then, based on the substantial cosinusoidal relationship between standardized vertical bias and topographical parameters (slope and aspect), the vertical biases and horizontal displacements were rectified. After these adjustments, elevation differences between SRTM C-band and X-band DEMs on glacier can be considered to be the SRTM C-band radar beam penetration depth.

The penetration depth differences were analyzed and corrected in each $100 \mathrm{~m}$ elevation bin on glacier. Because the penetration difference should not exceed $10 \mathrm{~m}$ (Gardelle and others, 2012a), all of the difference values $> \pm 10 \mathrm{~m}$ were defined as outliers and were not considered for the penetration estimation. The median values of each elevation bin were used to correct the SRTM C-band DEM but only for areas with elevations below $6200 \mathrm{~m}$ a.s.I. In the CNR, the penetration depth difference for clean ice/firn/snow was $\sim 0.88 \mathrm{~m}$ below $5200 \mathrm{~m}$, and $1.28 \mathrm{~m}$ between 5200 and $6200 \mathrm{~m}$. SRTM X-band DEM does not cover higher elevation region and penetration depth difference cannot be determined for regions above $6200 \mathrm{~m}$. According to the linear trend calculated for the several highest bins in Figure 3, a value of $2.26 \mathrm{~m}$ was assumed for the area above $6200 \mathrm{~m}$. For the debris-covered region, we did not apply any penetration corrections. In total, the average penetration depth of the SRTM C-band radar is $1.16 \mathrm{~m}$ for clean ice/firn/snow in the CNR. This value is consistent with previous studies finding an average penetration depth of $1.1 \mathrm{~m}$ in Yigong Tsangpo (Zhou and others, 2018).

\subsection{Mass balance and accuracy estimation}

In order to convert glacier-elevation changes to a geodetic mass balance, the glacier area and ice/firn/snow density must be considered. The geometric union of the 1968 and 2013 glacier masks was employed to respect maximum glacier extent between the dates of data acquisition ( $\mathrm{Li}$ and others, 2012; Neckel and others, 2013). An ice/firn/snow density of $850 \mathrm{~kg} \mathrm{~m}^{-3}$, with an uncertainty of $60 \mathrm{~kg} \mathrm{~m}^{-3}$, was applied to assess the w.e. of mass changes from elevation differences (Huss, 2013; Wei and others, 2015; Li and others, 2018).

Elevations from the ICESat Geoscience Laser Altimeter System (GLAS) were employed for a first accuracy assessment. These data are freely available from the National Snow and Ice Data Center (NSIDC) (release 634; product GLA14). Surface elevations of the DEMs were extracted at each ICESat footprint location. To ensure the accuracy of comparison, ICESat points were removed from the analysis if the elevation difference between GLA14 and multisource DEMs exceeded $100 \mathrm{~m}$ in off-glacier region. A mean and SD of $2.14 \pm 1.46 \mathrm{~m}$ and $1.95 \pm 1.76 \mathrm{~m}$ in offglacier regions were found for the TOPO and SRTM Cband DEMs, respectively. The GCPs used to convert the unwrapped TerraSAR-X/TanDEM-X interferogram into absolute heights from off-glacier pixel locations revealed that the vertical biases of the TerraSARX/TanDEM-X DEM and GLA 14 were similar to those of the SRTM C-band DEM and GLA 14.

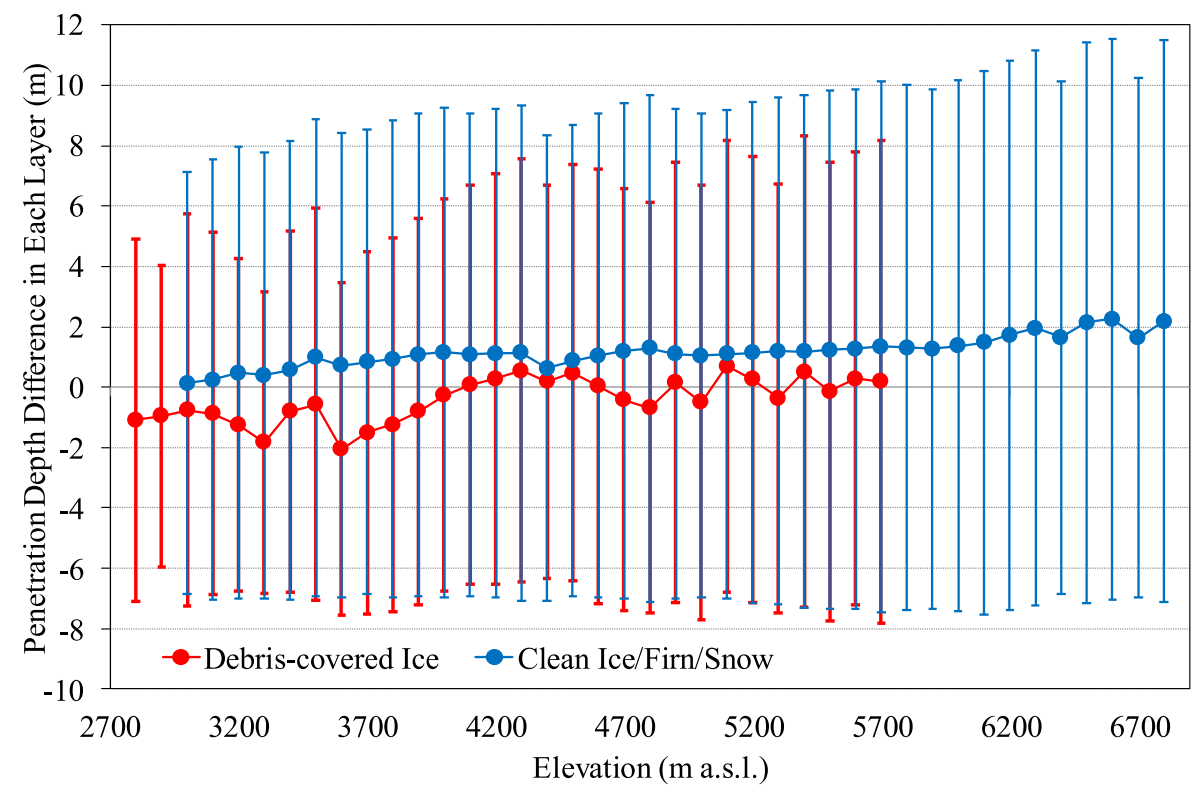

Fig. 3. Penetration depth differences between SRTM C-band and X-band DEMs at each elevation bin, red indicates debris-covered ice, while blue indicates clean ice/firn/snow. 
Table 3. Statistics of vertical errors between the TOPO, SRTM and TSX/TDX

\begin{tabular}{|c|c|c|c|c|c|c|}
\hline Region & Item & AED $m$ & STDV m & $N^{*}$ & SE $m$ & $\sigma^{\dagger} \mathrm{m}$ \\
\hline \multirow[t]{3}{*}{ 5N225E Basin } & SRTM-TOPO & -1.22 & 20.40 & 9421 & 0.21 & 1.24 \\
\hline & TSX/TDX-SRTM & -1.23 & 6.11 & 84762 & 0.02 & 1.23 \\
\hline & TSX/TDX-TOPO & -0.57 & 26.07 & 84762 & 0.09 & 0.58 \\
\hline \multirow[t]{3}{*}{ 5O281B Basin } & SRTM-TOPO & 1.13 & 27.51 & 14961 & 0.22 & 1.15 \\
\hline & TSX/TDX-SRTM & 0.68 & 17.43 & 134579 & 0.05 & 0.68 \\
\hline & TSX/TDX-TOPO & -0.64 & 32.55 & 134579 & 0.09 & 0.65 \\
\hline \multirow{2}{*}{ 5O282A Basin } & TSX/TDX-SRTM & 1.12 & 6.81 & 59281 & 0.03 & 1.12 \\
\hline & TSX/TDX-TOPO & 0.76 & 32.51 & 59281 & 0.13 & 0.77 \\
\hline \multirow[t]{3}{*}{ Total } & SRTM-TOPO & -1.24 & 24.76 & 30973 & 0.14 & 1.25 \\
\hline & TSX/TDX-SRTM & 0.79 & 12.09 & 278622 & 0.02 & 0.79 \\
\hline & TSX/TDX-TOPO & -0.69 & 30.21 & 278622 & 0.06 & 0.70 \\
\hline
\end{tabular}

AED, average elevation difference; STDV, standard deviation; SE, standard error.

* $N$, the number of considered pixels.

$\dagger \sigma$, the overall error of the derived surface elevation change.

To estimate the error in derived surface elevation changes, the residual elevation differences in off-glacier regions was calculated. The average elevation differences (AED) between the final difference maps in off-glacier regions ranged from -1.23 to $1.12 \mathrm{~m}$ (Table 3, Supplementary Fig. S1). The SD in off-glacier regions will probably overestimate the uncertainty of the larger sample because averaging in larger regions reduces the error. The uncertainty can be estimated by the standard error of the mean (SE) (Berthier and others, 2010):

$$
\mathrm{SE}=\mathrm{SD} / \sqrt{N}
$$

where $N$ is the number of the included pixels. To minimize the effect of autocorrelation, a decorrelation length based on the spatial resolution is recommended. For DEMs with a spatial resolution of $5 \mathrm{~m}$, a decorrelation length of $100 \mathrm{~m}$ is suitable (Koblet and others, 2010). Bolch and others (2011) used values of $600 \mathrm{~m}$ for the spatial resolution of 30 and $400 \mathrm{~m}$ for $10-20 \mathrm{~m}$. In this study, decorrelations of 600 and $200 \mathrm{~m}$ were employed for different DEMs with the spatial resolution of 30 and $10 \mathrm{~m}$. The extent of study area was divided into several pixels according to the decorrelation length, $N$ in Eqn (2) is the number of the included pixels in off-glacier area. In order to calculate the SE for a reasonable number of gridcells close to the glacier, only gridcells that located in a $5 \mathrm{~km}$ buffer around the glaciers were employed. The overall errors of derived surface-elevation changes can then be estimated using SE and AED in off-glacier regions:

$$
\sigma=\sqrt{\mathrm{AED}^{2}+\mathrm{SE}^{2}}
$$

Finally, the overall mass-balance errors were determined using the estimated errors of glacier area and surface elevation change, and the ice density uncertainty of $60 \mathrm{~kg} \mathrm{~m}^{-3}$ :

$$
E r r_{M B}=\left(\sigma A_{\text {max }}+(\Delta H+\sigma) E r r_{\text {area }}\right) \rho
$$

where $\operatorname{Err}_{M B}$ is the overall errors of mass balance, $\sigma$ is the overall errors of glacier elevation changes, $\Delta H$ is the mean glacier elevation changes, $A_{\max }$ is the maximum glacier extent between 1968 and 2013, Err area is the overall errors of glacier area and $\rho$ is the ice density of $910 \mathrm{~kg} \mathrm{~m}^{-3}$.

\section{RESULTS}

\subsection{Area change}

There were 715 glaciers with a total area of $1713.42 \pm 51.82$ $\mathrm{km}^{2}$ in 2016 in the CNR (Fig. 4). While large glaciers dominate the area (those $>1 \mathrm{~km}^{2}$ occupy $93.5 \%$ of the total area) small glaciers dominate the number (those $\leq 0.5 \mathrm{~km}^{2}$ occupy $69.4 \%$ of the total number) (Fig. 4a). Approximately $82.2 \%$ of the total glacier area is found between 4500 and $5800 \mathrm{~m}$ of elevation, $4.9 \%$ is below $4200 \mathrm{~m}$, and only $2.4 \%$ above $6200 \mathrm{~m}$. The median elevation is $\sim 5248 \mathrm{~m}$ (Fig. 4b). Kyagqen Glacier, the largest glacier $\left(153.07 \pm 0.43 \mathrm{~km}^{2}\right)$ has the lowest tongue at 2882 $\mathrm{m}$ a.s.l. The mean glacier surface slope in the CNR is $22.8^{\circ}$, with most in the $12-32^{\circ}$ range, accounting for $93.5 \%$ of total area. Glaciers having a SE, S or E aspect account for $85.5 \%$ of their area (Fig. $4 \mathrm{c}$ ).

The CNR contains almost 100 glaciers with significant debris cover. The total debris-covered area of $203.23 \mathrm{~km}^{2}$ represents $\sim 11.9 \%$ of the total glacierized area (Fig. 5). Among all the debris-covered glaciers, there were 12 glaciers with areas of debris cover that exceeded $5 \mathrm{~km}^{2}$. Nalong Glacier has the most in the CNR, $21.88 \mathrm{~km}^{2}$ or $\sim 28.0 \%$ of its area. On Kyagqen Glacier, the debris cover only accounts for $3.2 \%$ of its area. Some $89.4 \%$ of the debris-covered area is in the $3700-5100 \mathrm{~m}$ elevation range, $7.4 \%$ is below $3700 \mathrm{~m}$, and only $3.2 \%$ above $5100 \mathrm{~m}$. The lowest elevation of debris cover $(2882 \mathrm{~m})$ coincides with the lowest limit of Kyagqen Glacier. The upper limit of debris cover $(5754 \mathrm{~m})$ is on Glacier 5N225E0033, on the north slope of the CNR.

Comparing the total area of all glaciers in 1968 with that in 2016, ice cover in the CNR has diminished by $824.32 \pm$ $55.65 \mathrm{~km}^{2}(32.5 \pm 2.2 \%)$ or $0.68 \pm 0.05 \% \mathrm{a}^{-1}$ (Table 4$)$. Small glaciers shrank the most, but large glaciers dominated the absolute area loss (Fig. 4d). Analysis of glacier hypsography showed that the ice cover below $2800 \mathrm{~m}$, with an area of $0.32 \mathrm{~km}^{2}$, had disappeared completely, absolute area loss increased gradually with altitude through the 2800-5200 $\mathrm{m}$ a.s.l. range, then decreased gradually from 5200 to $6200 \mathrm{~m}$ a.s.l., remaining almost unchanged above $6200 \mathrm{~m}$. Glaciers with lower elevation tended to lose relatively more area than higher elevation glaciers (Fig. 4b). The average minimum elevation of the glaciers increased by $258 \mathrm{~m}$, while their median elevation rose $\sim 97 \mathrm{~m}$ from 

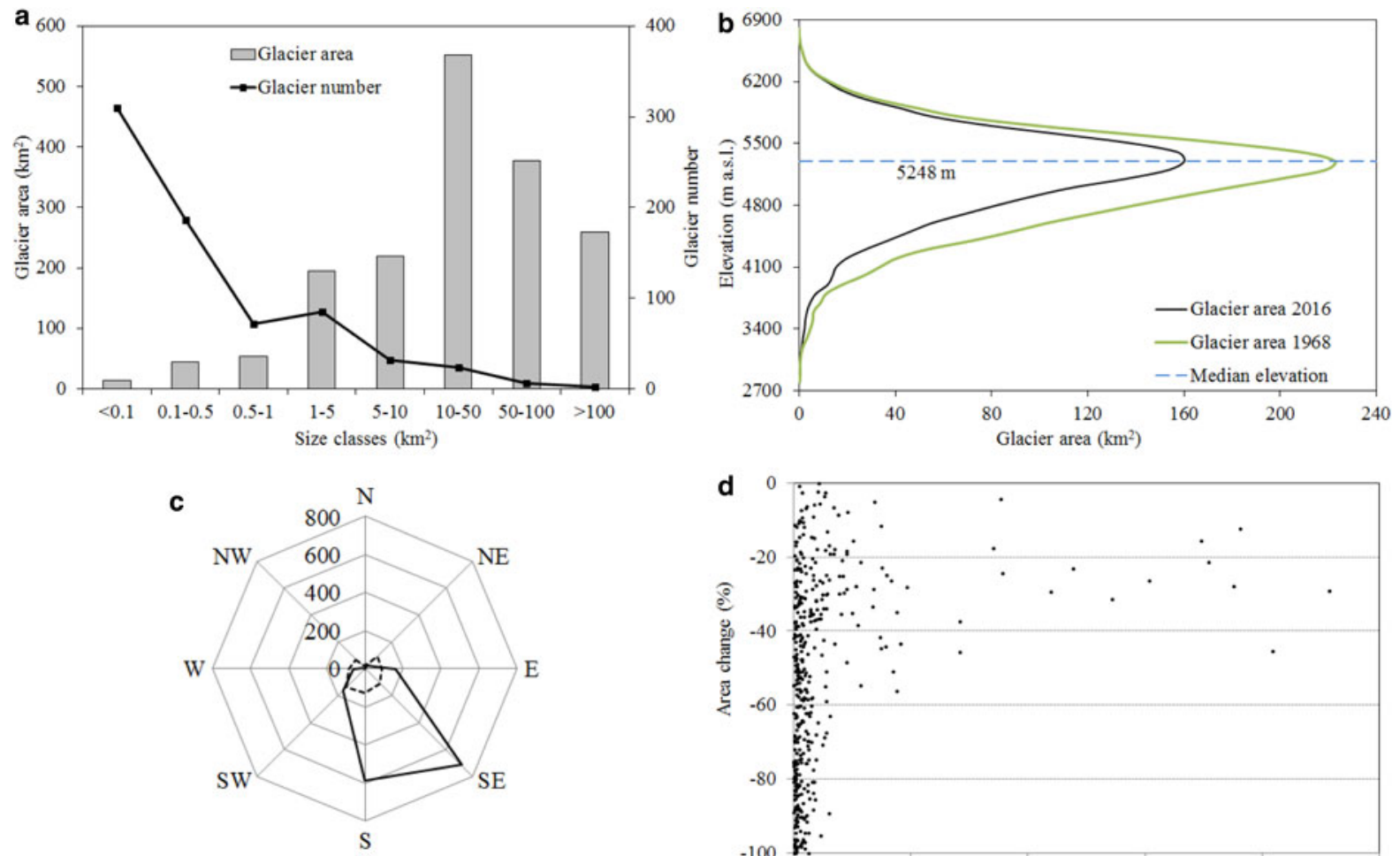

-.-.-Glacier number - Glacier area $\left(\mathrm{km}^{2}\right)$

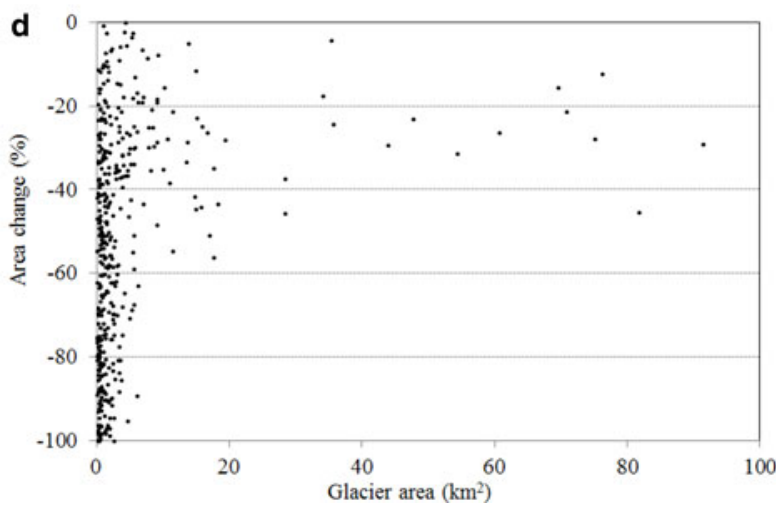

Fig. 4. Glacier distribution and change in the CNR. (a) Number and area of 2016 glaciers in different size categories. (b) Hypsography of glaciers in 1968 and 2016; the dashed line depicts the 2016 median elevation value. (c) Number and area of 2016 glaciers with different aspects. (d) Percentage change of glacier area from 1968 to 2016.

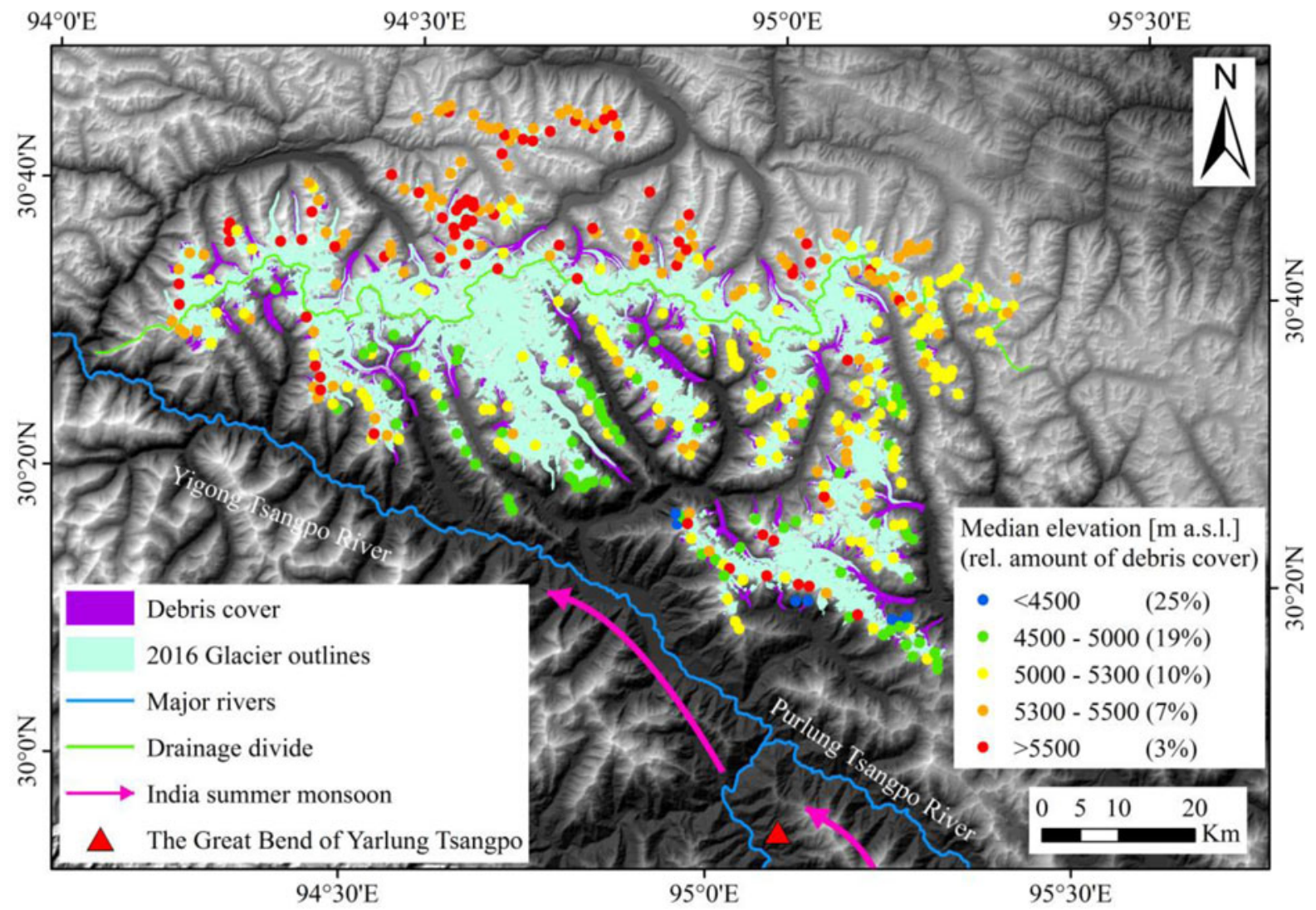

Fig. 5. Median glacier elevation and relative amount of debris cover is spatially correlated: median elevation is increasing from southeast to northwest, whereas the debris cover (indicated by the number in brackets in the legend) is decreasing along this gradient. The background map is SRTM DEM. 
Table 4. Glacier area changes in the CNR from 1968 to 2016

\begin{tabular}{|c|c|c|c|c|}
\hline \multirow[b]{2}{*}{ Drainage basin } & \multicolumn{2}{|c|}{ Glacier area $\mathrm{km}^{2}$} & \multicolumn{2}{|c|}{ Change of glacier area } \\
\hline & April 1968 & July 2016 & Percent change from 1968 to $2016 \%$ & Average change $\% \mathrm{a}^{-1}$ \\
\hline 5N225E & $316.25 \pm 3.63$ & $281.45 \pm 6.90$ & $-11.00 \pm 2.07$ & $-0.23 \pm 0.05$ \\
\hline $5 \mathrm{O} 281 \mathrm{~B}$ & $1863.99 \pm 20.62$ & $1167.01 \pm 30.71$ & $-37.39 \pm 1.98$ & $-0.78 \pm 0.04$ \\
\hline $5 \mathrm{O} 282 \mathrm{~A}$ & $357.50 \pm 3.87$ & $264.96 \pm 6.32$ & $-25.89 \pm 2.07$ & $-0.54 \pm 0.04$ \\
\hline Total & $2537.74 \pm 20.28$ & $1713.42 \pm 51.82$ & $-32.48 \pm 2.19$ & $-0.68 \pm 0.05$ \\
\hline
\end{tabular}

5151 to $5248 \mathrm{~m}$. Disintegration of glaciers into smaller bodies of ice compensated for the disappearance of a few glaciers so the overall number of glaciers increased. Those that had disappeared were small and situated at relatively low altitudes.

\subsection{Mass balance}

Significant glacier surface lowering has been observed in the CNR since 1968 with mass losses tending to increase during the most recent decade. Glaciers, with an area of $2624.30 \mathrm{~km}^{2}$ (the geometric union of the 1968 and 2016 glacier areas), experienced a mean thinning of $24.48 \pm 0.70 \mathrm{~m}$, or a mean mass loss of $0.46 \pm 0.10 \mathrm{~m}$ w.e. $\mathrm{a}^{-1}$, equivalent to an overall mass loss of $64.21 \pm 1.10 \mathrm{Gt}$ from 1968 to 2013 . The rate of thinning increased during the investigated periods. Glaciers thinned by $0.49 \pm 0.22 \mathrm{~m} \mathrm{a}^{-1}$, representing a mean mass loss of $0.42 \pm 0.20 \mathrm{~m}$ w.e. $\mathrm{a}^{-1}$ from 1968 to 2000. Surface lowering was $0.71 \pm 0.22 \mathrm{~m} \mathrm{a}^{-1}$ with a mean mass loss of $0.60 \pm 0.20 \mathrm{~m}^{2}$.e. $\mathrm{a}^{-1}$ from 2000 to 2013 (Fig. 6 and Supplementary Table S1). More details of elevation change are shown in Supplementary Figures S2-S5.

Glaciers on the south slope, with an area of $1896.36 \pm 20.39$ $\mathrm{km}^{2}$, experienced a mean mass loss of $0.46 \pm 0.09 \mathrm{~m}$ w.e. $\mathrm{a}^{-1}$ from 1968 to 2013, with means of $0.42 \pm 0.19 \mathrm{~m}$ w.e. $\mathrm{a}^{-1}$ and $0.56 \pm 0.17 \mathrm{~m}$ w.e. $\mathrm{a}^{-1}$ for $1968-2000$ and 2000-2013, respectively. Losses of $0.48 \pm 0.08 \mathrm{~m}$ w.e. $\mathrm{a}^{-1}$ on the north slope were close to those on the south slope from 1968 to 2013. Glaciers with an area of $727.94 \pm 4.31 \mathrm{~km}^{2}$ in the former experienced a mean mass loss of $0.40 \pm 0.20 \mathrm{~m}$ w.e. $\mathrm{a}^{-1}$ from 1968 to 2000 , and then increased significantly to $0.72 \pm 0.31 \mathrm{~m}$ w.e. $\mathrm{a}^{-1}$ from 2000 to 2013 .

Changes varied significantly between the different time intervals and individual glaciers, even for those in the same basin with a similar climate. In $5 \mathrm{O} 28$ basin, Star Glacier (5O282A0103) experienced the largest mass loss from 1968 to $2013\left(0.62 \pm 0.11 \mathrm{~m}\right.$ w.e. $\left.\mathrm{a}^{-1}\right)$ with losses much higher in the later period from 2000 to $2013(1.09 \pm 0.29 \mathrm{~m}$ w.e. $\mathrm{a}^{-1}$ ). Meanwhile Cape Glacier (5O282A0071), in the same drainage basin, experienced the smallest losses $\left(0.24 \pm 0.11 \mathrm{~m}\right.$ w.e. $\left.\mathrm{a}^{-1}\right)$ from 1968 to 2013 , with even less from 1968 to $2000\left(0.07 \pm 0.21 \mathrm{~m}\right.$ w.e. $\left.\mathrm{a}^{-1}\right)$. Accelerating mass losses occurred on most sample glaciers, except for one glacier in the $5 \mathrm{~N} 225 \mathrm{E}$ basin and two in 5O281B, where the rate of mass loss decreased.

\section{DISCUSSION}

\subsection{Uncertainty}

The error in the derived glacier mass balance can result from both systematic and random components ( $\mathrm{Li}$ and others, 2018). The latter comes from the precision of TerraSAR-X/
TanDEM-X acquisitions, SRTM DEMs and TOPO DEMs, as well as the total glacier area measured. The systematic component includes errors in the seasonal effects and penetration depth.

Since geodetic measurements should determine mass balances ideally corresponding to an integer number of balance years, the seasonal variance of glacier mass balances needs to be considered (Gardelle and others, 2012b). In the CNR, maritime (temperate) glaciers develop and receive abundant summer monsoon precipitation. Most accumulation and melting occur simultaneously in the summer. TerraSAR-X/ TanDEM-X and SRTM DEMs are acquired in February, and TOPO DEMs are acquired in April. To evaluate seasonal effects, glacier mass budgets determined from TOPO DEMs and TerraSAR-X/TanDEM-X or SRTM DEMs should be adjusted to the state of glaciers in February based on massbalance variations. The annual distribution of mass balance is difficult to establish in the study area because field measurements are lacking. It has been assumed, conservatively, that precipitation is totally converted into mass accumulation. Based on the Dataset of Daily $0.5^{\circ} \times 0.5^{\circ}$ Grid-based Precipitation in China (V2.0), the total precipitation in the study area from February to April in 1968 was $321 \mathrm{~mm}$, which could create errors of up to $\sim 0.01 \mathrm{~m}$ w.e. $\mathrm{a}^{-1}$ for the mass balances of 1968-2000 and 1968-2013. Compared with other factors in this study, any errors arising from the seasonal variance of mass balances can be considered negligible.

Another critical unknown is C-band radar penetration into snow and ice when SRTM C-band DEMs are used for geodetic mass-balance calculations. Penetration depths of 2.1$4.7 \mathrm{~m}$ at $10 \mathrm{GHz}$ were measured in the Antarctic (Davis and Poznyak, 1993), where the depth decreases as the temperature and water content of the surface snow increases (Surdyk, 2002). Glaciers in the CNR are predominantly influenced by the monsoon and have higher snow moisture and temperatures than the Antarctic (Shi and Liu, 2000). Hence, the assumption is that the penetration of the X-band radar is small, the difference between SRTM C- and X-band DEMs were used to estimate the absolute penetration of Cband. In total, the average penetration depth of the SRTM C-band radar is $1.16 \mathrm{~m}$ for clean ice/firn/snow in the CNR. This value is slightly smaller than that of Gardelle and others (2013), however, its possible penetration can be considered. The correction for C-band radar penetration led to average mass changes of $+0.03 \mathrm{~m}$ w.e. $\mathrm{a}^{-1}$ for $1968-2000$ and $-0.08 \mathrm{~m}$ w.e. $\mathrm{a}^{-1}$ for $2000-2013$.

\subsection{Glacier inventory and changes of glacier area}

The median elevation of a glacier is widely used to estimate the long-term equilibrium line altitude (Braithwaite and 

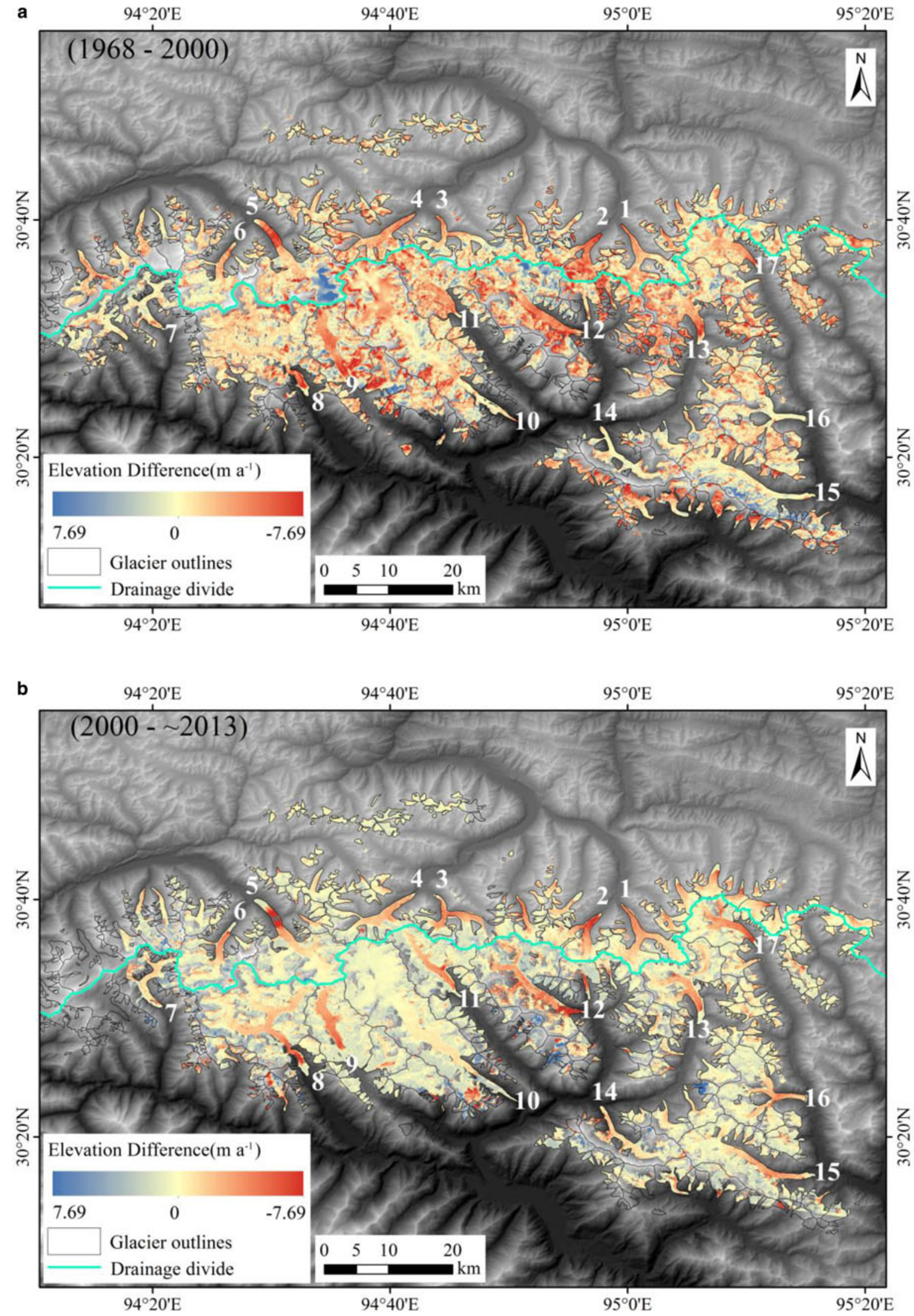

Fig. 6. Elevation changes in the CNR from 1968 to 2013. The glacier outlines are based on the geometric union of the 1968 and 2016 glacier extents. The background map is SRTM DEM. Numbers indicate specific sample glaciers chosen for analysis. (a) Elevation change from 1968 to 2000; (b) elevation change from 2000 to 2013 and (c) elevation change from 1968 to 2013.

Raper, 2009), and is suitable for analyzing the governing climatic conditions (Ke and others, 2016). Heterogeneous median elevations were detected in the CNR, and the spatial distribution of them reflects their climate dependence. This study area is located north of the Yarlung Tsangpo River where an important moisture transport path of the South 


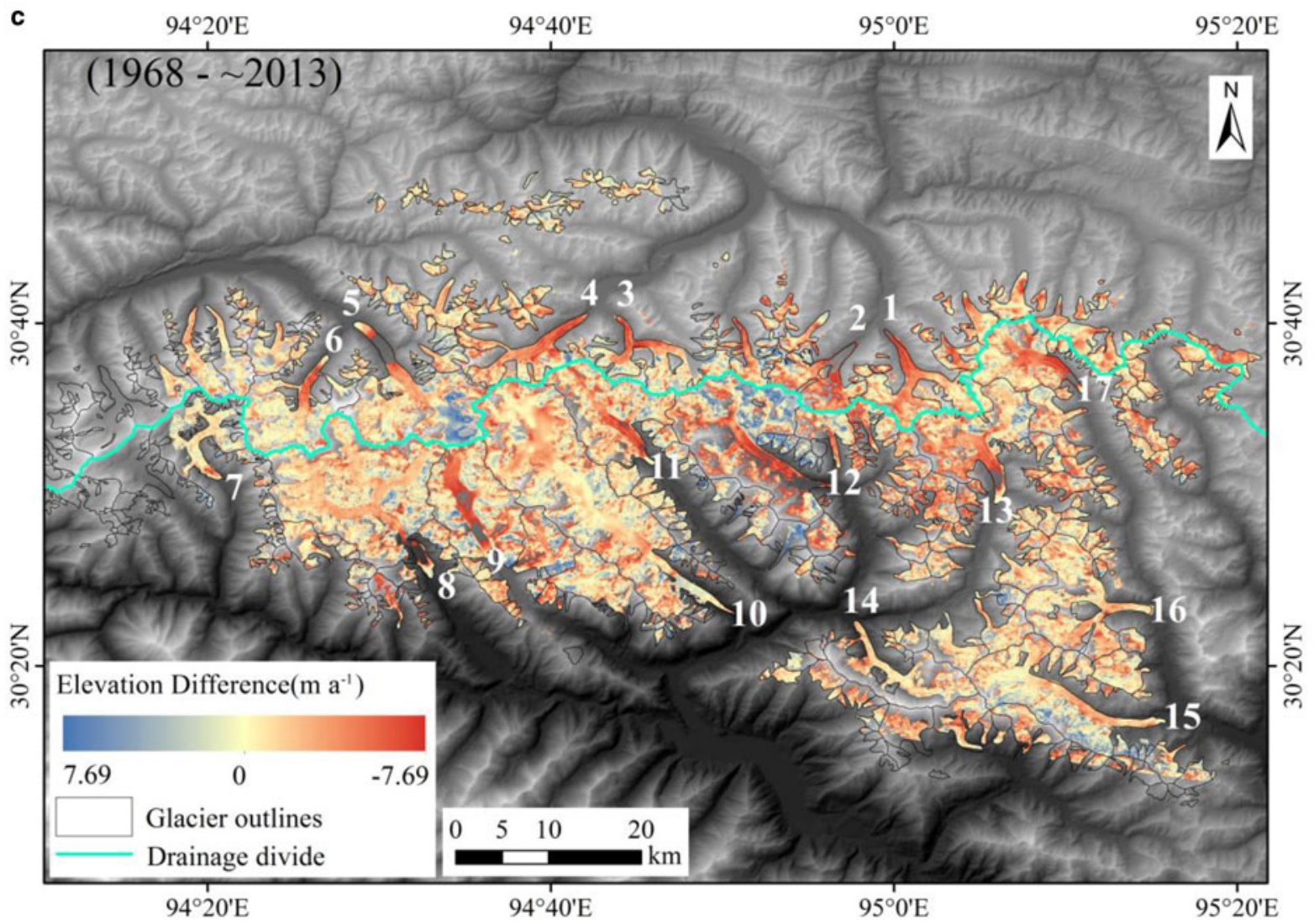

Fig. 6. (Continued)

Asian monsoon enters the plateau. From the Great Bend of the Yarlung Zangbo, the median elevation increases in SENW directions (Fig. 5). On the SE slope of the CNR, the South Asian monsoon brings abundant moisture, resulting in a relatively maritime climate and a lower median glacier elevation (below $5000 \mathrm{~m}$ ). Because the high-mountain ranges block water vapor transport to the leeward side, a higher median glacier elevation (above $5300 \mathrm{~m}$ ) is found on the NW slope. Conversely, if we classify the glaciers by median elevation first and then calculate the average debris cover for each class, it is found that the amount of debris cover for the median elevation classes decreases from $25.2 \%$ on the SE slope (median elevation $<4500 \mathrm{~m}$ ) to only $2.9 \%$ on the NW slope (median elevation $>5500 \mathrm{~m}$ ). The main reasons for this are probably an intensive debris supply from the steep rock walls facing south, the different geology of the SE and NW slopes, and autocorrelation effects between glaciers and the debris cover, i.e. the high amount of debris cover on low elevation glacier parts can be caused by the insulating effect of the debris itself (Kääb, 2005; Frey and others, 2012; Ke and others, 2016). Due to the insulating effect of the debris cover, the glacier terminus retreats more slowly. The amount of debris cover on the SE slope is larger than that on the NW slope, resulting in lower elevation glacier termini and a lower median glacier elevation on the SE slope than that on the NW slope.

Due to the influence of the South Asian monsoon, the CNR was almost permanently covered by snow and cloud, so the higher-quality optical-satellite images were rarely available from 2000 to 2010. Using 356 Landsat ETM+ scenes in 226 path-row sets from 1999 to 2003, Nuimura and others (2015) compiled the GAMDAM inventory
(Glacier Area Mapping for Discharge from the Asian Mountains). There was a larger discrepancy between this and the $2000 \mathrm{CGl}$ in the western Nyainqentanglha Range, probably because the GAMDAM inventory excluded thin ice on headwalls, the effects of shadow and seasonal snow cover, and tended to include smaller areas than those recommended by the GLIMS guidelines (Arendt and others, 2015; $\mathrm{Wu}$ and others, 2016). An improved glacier inventory of the SE Tibetan Plateau (SETPGI) was compiled from Landsat images acquired from 2011 to 2013, coherence images from ALOS/PALSAR images and the SRTM DEM (Ke and others, 2016). Comparing the SETPGI with our 2016 inventory, a slight discrepancy of glacier area (3.7\%) was found which can be accounted for by a change in glacier area of $-0.62 \% \mathrm{a}^{-1}$ from 2010 to 2016 . Meanwhile comparing the SETPGI with our 1968 inventory, ice cover in the CNR has diminished by $-0.75 \% \mathrm{a}^{-1}$ from 1968 to 2010 . It was concluded that the glaciers in the study area have shrunk continuously since $1968\left(-0.75 \% \mathrm{a}^{-1}\right.$ from 1968 to 2010 and $0.62 \% \mathrm{a}^{-1}$ from 2010 to 2016 ), although the rate has eased during the most recent decade. The main reasons for this eased tendency are probably the effect of debris cover, which slowdown the retreat of glacier terminus.

\subsection{Changes of glacier elevation and mass balance}

Previous studies agreed that glaciers in the CNR were losing mass, though results differed from each other. Based on SRTM and SPOT5 DEMs (24 November 2011), a mean thinning of $0.39 \pm 0.16 \mathrm{~m} \mathrm{a}^{-1}$ was found between 2000 and 2011 by Gardelle and others (2013), whereas different rate of $1.34 \pm 0.29 \mathrm{~m} \mathrm{a}^{-1}$ from 2003 to 2008 was recorded over 

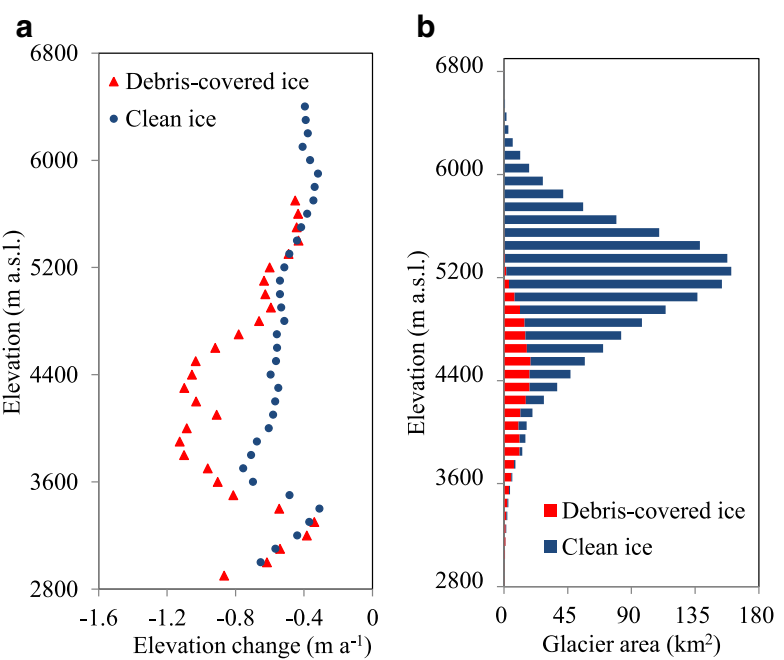

Fig. 7. Glacier elevation changes and distribution of 2016 glacier area at each $100 \mathrm{~m}$ interval by altitude in the CNR for clean ice and debris-covered ice from 1968 to 2013.

the CNR by Kääb and others (2015), using ICESat and SRTM. In this study, SRTM DEM and TerraSAR-X/TanDEM-X acquisitions yielded a mean thinning of $0.54 \pm 0.05 \mathrm{~m} \mathrm{a}^{-1}$ from 2000 to 2013. At a first glance, this result agrees with Gardelle and others (2013) but has significant difference from Kääb and others (2015). Different estimates of SRTM $\mathrm{C}$-band penetration have resulted in thinnings at variance with those determined by Kääb and others (2015). An average SRTM C-band penetration of 8-10 m (7-9 m when based on winter trends assumed to reflect February conditions) was used for the eastern Nyainqentanglha Mountains in the Kääb and others (2015) study, much greater than the $1.7 \mathrm{~m}$ assumed in the study of Gardelle and others (2013) and $1.16 \mathrm{~m}$ assumed in this study. Previous studies suggested an average penetration of $2.4 \mathrm{~m}$ in Bhutan and $1.4 \mathrm{~m}$ around the Everest (Gardelle and others, 2013), $2.26 \mathrm{~m}$ for clean ice below $6000 \mathrm{~m}$ in the Mount Everest region ( $\mathrm{Li}$ and others, 2018), $2.5 \pm 0.5 \mathrm{~m}$ for a wider area including east Nepal and Bhutan (Kääb and others, 2012), $1.67 \pm 0.53 \mathrm{~m}$ in the western Nyainqentanglha Mountains (Li and Lin, 2017) and $1.24 \mathrm{~m}$ in the Kangri Karpo Mountains ( $\mathrm{Wu}$ and others, 2018). Because the CNR lies in the center of the eastern Himalaya, western Nyainqentanglha Mountains and Kangri Karpo Mountains, the characteristics of glacier in the CNR are similar to the surrounding regions (Shi and Liu, 2000). Since penetration depth varies with temperature and water content (Surdyk, 2002), an average penetration of $1.16 \mathrm{~m}$, in agreement with previous studies, was deemed acceptable and suitable for estimating glacier elevation changes in the CNR.

Brun and others (2017) recorded a mean mass loss of 0.62 $\pm 0.23 \mathrm{~m}$ w.e. $\mathrm{a}^{-1}$ between 2000 and 2016 in the
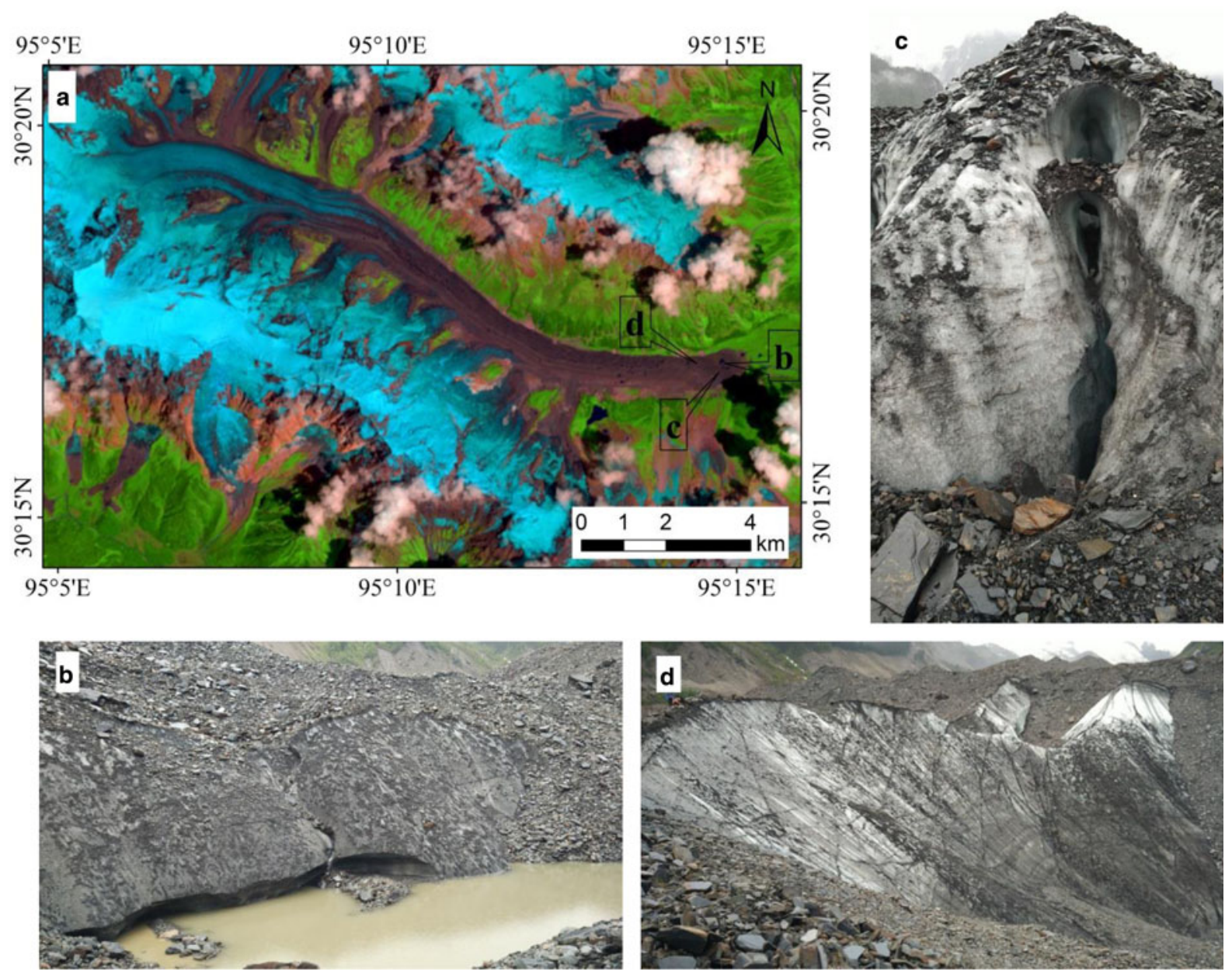

Fig. 8. The debris-covered tongue of Cape Glacier with supraglacial lakes and ice cliffs: (a) the background image is a Landsat OLI image (4 Aug 2013, RGB:743. The letters on the tongue of Cape Glacier correspond to photo panels in this figure); (b) supraglacial lake; (c) and (d) ice cliffs (photos taken by K. P. Wu, 12 June 2015). 


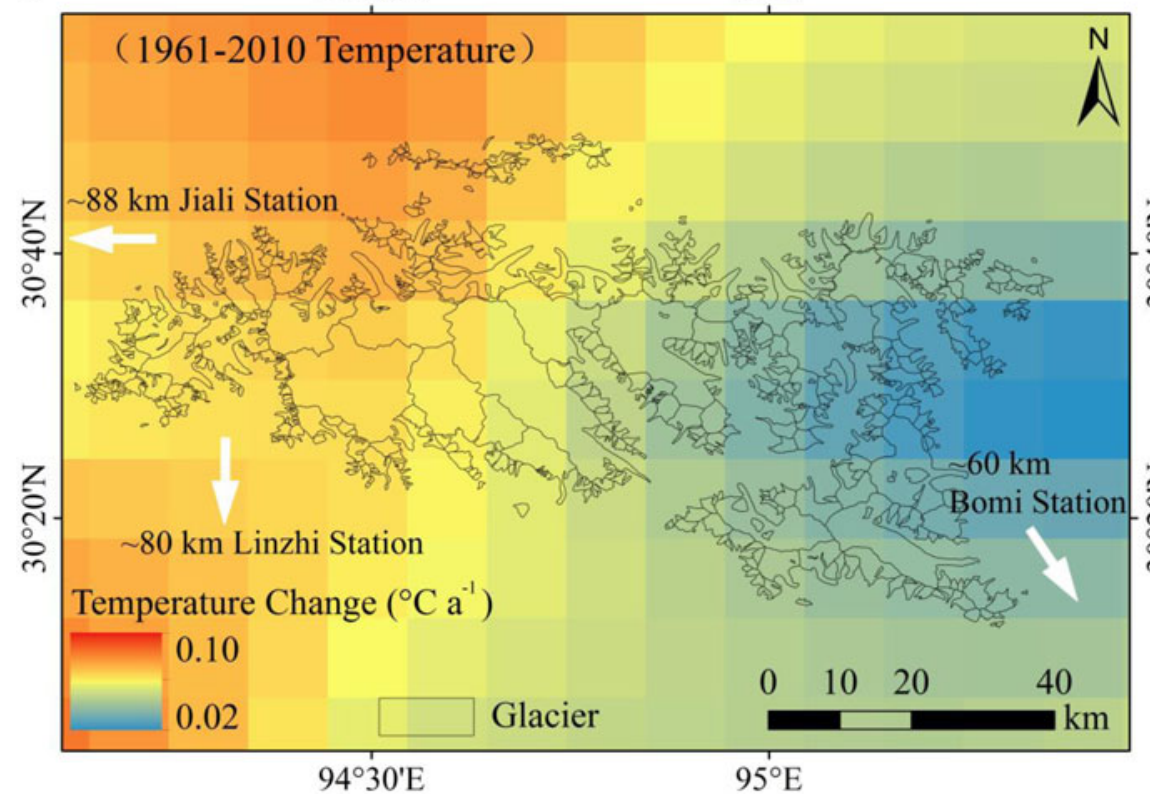

b $94^{\circ} 30^{\prime} \mathrm{E}$

$95^{\circ} \mathrm{E}$

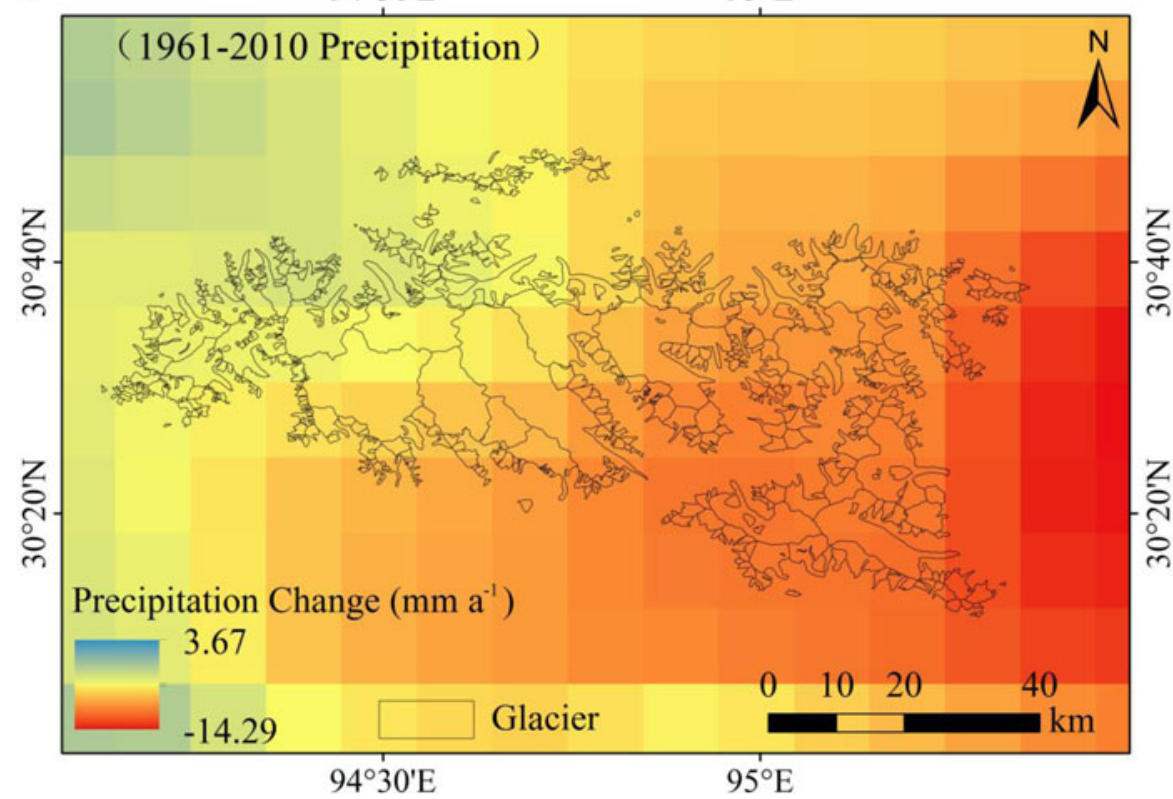

Fig. 9. The changes of temperature and precipitation (from May to September) in the CNR from Dataset2.0 during 1961-2010: (a) temperature and (b) precipitation.

Nyainqentanglha Range, based on ASTER optical satellite stereo pairs. Because this result relies exclusively on satellite optical data, it is not affected by signal penetration. Our determination of a mean mass loss of $0.60 \pm 0.20 \mathrm{~m}$ w.e. $\mathrm{a}^{-1}$ from 2000 to 2013 in the CNR agrees with that Brun and others (2017) and suggests our results are reliable. A larger discrepancy is noted with the Zhou and others (2018) results in Yigong Tsangpo from declassified $\mathrm{KH}-9$ images (21 December 1975) and SRTM DEMs; $0.11 \pm 0.14$ m w.e. $\mathrm{a}^{-1}$ vs our result of $0.42 \pm 0.20 \mathrm{~m}$ w.e. $\mathrm{a}^{-1}$ from 1968 to 2000 . There are likely three reasons for this discrepancy: first, a difference in dates of the declassified $\mathrm{KH}-9$ images and topographic maps; second, a difference in the glacier area measured. The Yigong Tsangpo study measured a glacier area of $1055 \mathrm{~km}^{2}$ while ours was $2622.95 \mathrm{~km}^{2}$. Third, there are differences in how data voids in the accumulation area are filled.
Ice in the comparatively flat lower parts of the larger valley glaciers is much thicker than that in the steep higher glacier reaches, due to the generalized flow law of ice (assumption of perfect plasticity) (Cuffey and Paterson, 2010). In other words, a large amount of the glacier volume is stored in the low-lying ablation regions, as median elevation separates glaciers in two halves of equal size. This suggests that large amounts of ice can become subject to melt in the event of climate warming. Whereas the mass-loss patterns on a debris-covered tongue are complicated, with supraglacial lakes, ice cliffs and heterogeneous debris cover (Pellicciotti and others, 2015). Although it is generally believed that ablation rates are retarded with a thick debris cover due to its insulating effect (Benn and Lehmkuhl, 2000), some previous studies have found that ablation is greater when the debris is less than a critical thickness (Zhang and others, 2011, 2016; Ye and others, 2015). In this study, the surface properties 

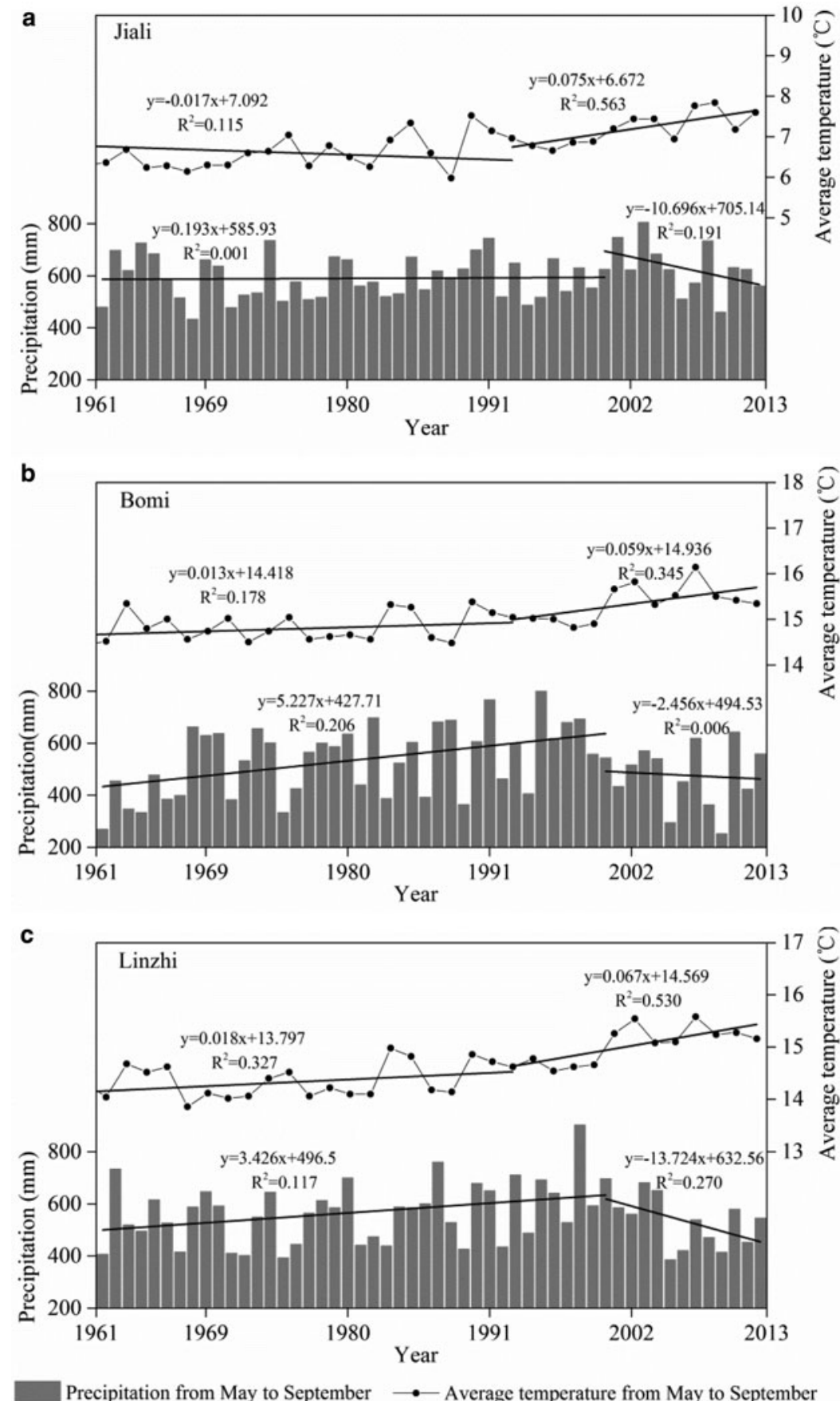

Fig. 10. Annual variations of average temperature and precipitation (from May to September) around the CNR: (a) Jiali, (b) Bomi and (c) Linzhi, and linear trends are shown as black solid lines.

have a positive influence on the melt: thinning was noticeably greater on the debris-covered ice than the clean ice in the 2800-5700 $\mathrm{m}$ a.s.l. range from 1968 to 2013 in the CNR $\left(0.92 \pm 0.10\right.$ vs $\left.0.51 \pm 0.10 \mathrm{~m} \mathrm{a}^{-1}\right)$ (Fig. 7). Similar results have been found in the eastern Pamir (Zhang and others, 2016), the Karakoram (Gardelle and others, 2012b), the western Himalaya (Berthier and others, 2007; Frey and others, 2012) and the Mount Everest region (Bolch and others, 2008).

Apart from debris cover, there are other features that may affect surface elevation changes, such as supraglacial/proglacial lakes, and ice cliffs. Although ice cliffs account for a small proportion of the total debris-covered area, they can make a disproportionate contribution to total ablation
(Sakai and others, 2002; Han and others, 2010; Benn and others, 2012). On steep slopes, heavy debris slides off leaving very fine debris on the ice cliffs. This reduces the ice albedo so the cliffs absorb more shortwave radiation, which is augmented by longwave radiation from the adjacent warm debris layers (Reid and Brock, 2014). Figure 8 shows the debris cover on Cape Glacier, its ice cliffs, and supraglacial lake. Compared with the clean ice in the 2800-5700 m a.s.l. range in the $\mathrm{CNR}$, the thin debris cover, exposed ice cliffs and supraglacial/proglacial lakes would contribute to the greater thinning rate observed on debris-covered glaciers in the CNR.

Different thinning rates were detected for land-terminating glaciers and lake-terminating glaciers in the CNR. Land- 
terminating glaciers with heavy debris-covers (5N225E0005, 5N225E0031, Yenong, Xiaqu, Kyagqen, Nalong, Maguolong, Yangbiegong, Cape and North Cape) experienced a mean thinning of $0.53 \pm 0.10 \mathrm{~m} \mathrm{a}^{-1}$ from 1968 to 2013, which was smaller slightly than the regional average $\left(0.54 \pm 0.10 \mathrm{~m} \mathrm{a}^{-1}\right)$. Surface lowering of all lake-terminating glaciers (5N225E0010, 5N225E0033, Jiongla, Lepu, Daoge, Ruoguo and Star) was $0.62 \pm 0.10 \mathrm{~m} \mathrm{a}^{-1}$, or higher than the regional average. These results are in agreement with previous studies of surface thinning on land and lake-terminating glaciers (Neckel and others, 2017; Li and others, 2018).

\subsection{Climate change}

Based on temperature data from 79 meteorological stations on the TP, the SE TP was the area with the least warming, compared with the rest of the TP (Duan and others, 2015). Conversely, the MODIS land surface temperature (MODIS LST) showed that the SE TP experienced the most warming (Yang and others, 2014). The National Centers for Environmental Prediction/National Center for Atmospheric Research (NCEP/NCAR) reanalysis data results indicated a decreasing trend of average annual temperature during 1961-2004 (You and others, 2010). Similarly with precipitation, a negative trend in the SE TP was shown by Global Precipitation Climatology Project (GPCP) data (Yao and others, 2012), while a positive trend came from Chinese meteorological station annual precipitation data ( $\mathrm{Li}$ and others, 2010). Thus, glacier changes in the CNR cannot be related directly to these contrasting summaries of climate information.

To analyze the response of glaciers in the CNR to climate change, relevant air temperature and precipitation datasets were taken from the Dataset of Daily $0.5^{\circ} \times 0.5^{\circ}$ Gridbased Temperature/Precipitation in China (V2.0) (Dataset2.0). Using the thin plate smooth spline method, and a 50 year (1961-2010) quality controlled observational daily temperature and precipitation data series based on 2472 gages (http://data.cma.cn/data/cdcindex/cid/ 00f8a0e6c590ac15.html), Dateset2.0 was produced by the Climate Data Center, National Meteorological Information Center, China meteorological Administration for Mainland China. A previous study showed that the mean bias error of precipitation in most gages is between -1 and $1 \mathrm{~mm} \mathrm{~d}^{-1}$ (Zhao and Zhu, 2015). Dataset2.0 underestimates the rain intensity during heavy or moderate rainfall events. Over the light rain, it has more veracity. Dataset2.0 describes the climate characteristic of the TP, the Tienshan Mountains and Tarim Basin (Zhao and Zhu, 2015).

To calculate temperature and precipitation trends between 1961 and 2010, linear regression analysis was performed for each gridcell. Figure 9 shows the horizontal distribution of surface temperature and precipitation changes from May to September since 1961, with a confidence level $<0.1$. It is clear that increasing surface temperatures and decreasing precipitation have been dominant in the CNR in recent decades. The changes in surface temperature and precipitation were confirmed with data from the three nearest meteorological stations, Jiali $\left(30^{\circ} 40^{\prime} \mathrm{N}, 93^{\circ} 17^{\prime} \mathrm{E}, 4488\right.$ $\mathrm{m}$ a.s.l. $),$ Bomi $\left(29^{\circ} 52^{\prime} \mathrm{N}, 9^{\circ} 46^{\prime} \mathrm{E}, 2736 \mathrm{~m}\right.$ a.s.l. $)$ and Linzhi $\left(29^{\circ} 40^{\prime} \mathrm{N}, 94^{\circ} 20^{\prime} \mathrm{E}, 2992 \mathrm{~m}\right.$ a.s.l.). Surface temperature at these stations increased slightly from 1961 to 2000 and then significantly after 2000. Average temperatures at Jiali, Bomi and Linzhi station after 2000 increased $0.45,0.67$ and $0.86{ }^{\circ} \mathrm{C}$ than those before 2000, respectively. Trends in precipitation are not evident at the three stations, which present large interannual precipitation fluctuations (Fig. 10).

Dataset2.0 shows average precipitation decreasing by more than $4 \mathrm{~mm} \mathrm{a}^{-1}$ since 1961 , resulting in less glacier accumulation. The average surface temperature increased by more than $0.2{ }^{\circ} \mathrm{C}$ per decade in the CNR (with a confidence level $<0.05$ ), higher than the rate of global warming $\left(0.12{ }^{\circ} \mathrm{C}\right.$ per decade, 1951-2012) (IPCC, 2013). The reduced precipitation on the north slope is smaller than on the south slope, while the warming rate on the north slope is larger than that on the south slope. Therefore, the observed mass loss in the CNR is consistent with observed increases in temperature and decreases in precipitation. Analysis of drivers of sub-period glacier mass changes requires additional information and modeling. The mean mass loss before 2000 was smaller than that after 2000 in the CNR, glacier changes were consistent with climate warming. And the mass loss in the $5 \mathrm{~N} 22$ drainage basin (on the north slope) was larger than that in the $5 \mathrm{O} 28$ drainage basin (on the south slope) during 2000-2013, resulting from the difference of precipitation decreasing. It is concluded that glacier mass loss in the CNR can be attributed to climate warming and precipitation decreasing.

\section{CONCLUSION}

Based on Topographical Maps, Landsat TM/ETM+/OLI images, SRTM and TerraSAR-X/TanDEM-X acquisitions, the changes of glacier area, surface elevation and mass balance in the $\mathrm{CNR}$ during recent decades have been estimated.

Results show that the CNR contained 715 glaciers, with a total area of $1713.42 \pm 51.82 \mathrm{~km}^{2}$ in 2016 . Ice cover has diminished by $0.68 \pm 0.05 \% \mathrm{a}^{-1}$ since 1968 , but the rate of glacier shrinkage has lessened during the most recent decade. Compared with the recession of mountain glaciers in western China, those in the CNR have experienced extremely strong retreat. Overall, the area covered by debris accounts for $11.9 \%$ of the whole ice cover, with the coverage decreasing in SE-NW directions.

Significant surface lowering of glaciers has been observed since 1968, and mass losses have increased in recent decades. Thinning was noticeably greater on the debriscovered ice than the clean ice in the 2800-5700 m a.s.l. altitude range from 1968 to 2013. Aside from debris cover, other features increasing glacier surface melting include proglacial/supraglacial lakes, and ice cliffs. Observed glacier mass changes in the CNR region are consistent with increased temperatures and decreased precipitation observed from gridded meteorological observations.

\section{SUPPLEMENTARY MATERIAL}

The supplementary material for this article can be found at https://doi.org/10.1017/jog.2019.20

\section{ACKNOWLEDGEMENTS}

This work was supported by the fundamental program of the National Natural Science Foundation of China (grant no. 41801031), the Ministry of Science and Technology of China (MOST) (grant no. 2013FY111400), the project of State Key Laboratory of Cryospheric Science (grant no. 
SKLCS-OP-2019-07), the National Natural Science Foundation of China (grant nos. 41190084, 41671057, 41671075 and 41701087), the International Partnership Programme of the Chinese Academy of Sciences (grant no. $131 \mathrm{C} 11 \mathrm{KYSB} 20160061)$ and the grant for talent introduction of Yunnan University. Landsat images are from the US Geological Survey and NASA. The TerraSAR-X/TanDEM-X images are from the DLR. The GAMDAM glacier inventory was provided by A. Sakai. The first and second glacier inventories were provided by a recent MOST project (2006FY110200). The Dataset of Daily $0.5^{\circ} \times 0.5^{\circ}$ Gridbased Temperature/Precipitation in China (V2.0) is from the China Meteorological Data Service Center (CMDC) in Beijing. All SAR processing was performed with GAMMA SAR and interferometric processing software. We thank DLR for free access to SRTM X-band data and USGS for free access to SRTM C-band and Landsat data.

\section{REFERENCES}

Arendt A and 87 others (2015) Randolph glacier inventory - a dataset of global glacier outlines. Version 5.0. Boulder, CO, University of Colorado. National Snow and Ice Data Center (NSIDC). Global Land Ice Measurements from Space (GLIMS), digital media, 63 pp (www.glims.org/RGl/00_rgi50_TechnicalNote.pdf)

Bao W, Liu S, Wei J and Guo W (2015) Glacier changes during the past 40 years in the West Kunlun Shan. J. Mt. Sci., 12(2), 344-357 (doi: 10.1007/s11629-014-3220-0)

Benn DI and Lehmkuhl F (2000) Mass balance and equilibrium-line altitudes of glaciers in high-mountain environments. Quat. Int., 65-66, 15-29 (doi: 10.1016/S1040-6182(99)00034-8)

Benn DI and 9 others (2012) Response of debris-covered glaciers in the Mount Everest region to recent warming, and implications for outburst flood hazards. Earth-Sci. Rev., 114(1-2), 156-174 (doi: 10.1016/j.earscirev.2012.03.008)

Berthier E, Arnaud Y, Vincent C and Rémy F (2006) Biases of SRTM in high-mountain areas: implications for the monitoring of glacier volume changes. Geophys. Res. Lett., 33(8), L08502 (doi: 10.1029/2006GL025862)

Berthier E and 5 others (2007) Remote sensing estimates of glacier mass balances in the Himachal Pradesh (Western Himalaya, India). Remote Sens. Environ., 108(3), 327-338 (doi: 10.1016/j. rse.2006.11.017)

Berthier E, Schiefer E, Clarke GKC, Menounos B and Rémy F (2010) Contribution of Alaskan glaciers to sea-level rise derived from satellite imagery. Nat. Geosci., 3(2), 92-95 (doi: 10.1038/ ngeo737)

Böhner J (2006) General climatic controls and topoclimatic variations in Central and High Asia. Boreas, 35, 279-295

Bolch T, Buchroithner M, Pieczonka T and Kunert A (2008) Planimetric and volumetric glacier changes in the Khumbu Himal, Nepal, since 1962 using Corona, Landsat TM and ASTER data. J. Glaciol., 54(187), 592-600 (doi: 10.3189/ 002214308786570782)

Bolch T, Menounos B and Wheate R (2010a) Landsat-based inventory of glaciers in western Canada, 1985-2005. Remote Sens. Environ., 114(1), 127-137 (doi: 10.1016/j.rse.2009.08.015)

Bolch $\mathrm{T}$ and 7 others (2010b) A glacier inventory for the western Nyainqentanglha Range and Nam Co Basin, Tibet, and glacier changes 1976-2009. Cryosphere, 4(3), 419-433 (doi: 10.5194/ tc-4-419-2010)

Bolch T, Pieczonka T and Benn DI (2011) Multi-decadal mass loss of glaciers in the Everest area (Nepal Himalaya) derived from stereo imagery. Cryosphere, 5(2), 349-358 (doi: 10.5194/tc-5-3492011)

Braithwaite RJ and Raper SCB (2009) Estimating equilibrium line altitude (ELA) from glacier inventory data. Ann. Glaciol., 50(53), 127-132 (doi: 10.3189/172756410790595930)
Brun F, Berthier E, Wagnon P, Kääb A and Treichler D (2017) A spatially resolved estimate of High Mountain Asia glacier mass balances from 2000 to 2016. Nat. Geosci., 10(9), 668-673 (doi: 10.1038/ngeo2999)

Chinese National Standard (2008) Compilation specifications for national fundamental scale maps. Part 1: Compilation specifications for 1:25000/1:50000/1:100000 topographic maps. Beijing, General Administration of Quality Supervision, Inspection and Quarantine, GB/T 12343.1-2008 [in Chinese]

Cuffey KM and Paterson WSB (2010) The physics of glaciers, 4th edn. Elsevier. Butterworth-Heinemann, Amsterdam, 488 pp

Davis CH and Poznyak VI (1993) The depth of penetration in Antarctic firn at $10 \mathrm{GHz}$. IEEE Trans. Geosci. Remote Sens., 31 (5), 1107-1111 (doi: 10.1109/36.263784)

Duan J, Li L and Fang Y (2015) Seasonal spatial heterogeneity of warming rates on the Tibetan Plateau over the past 30 years. Sci. Rep., 5, 11725 (doi: 10.1038/srep11725)

Frey H, Paul F and Strozzi T (2012) Compilation of a glacier inventory for the western Himalayas from satellite data: methods challenges and results. Remote Sens. Environ., 124, 832-843 (doi: 10.1016/j.rse.2012.06.020)

Gardelle J, Berthier E and Arnaud Y (2012a) Impact of resolution and radar penetration on glacier elevation changes computed from DEM differencing [Correspondence]. J. Glaciol., 58(208), 419422 (doi: 10.3189/2012JoG11J175)

Gardelle J, Berthier E and Arnaud Y (2012b) Slight mass gain of Karakoram glaciers in the early twenty-first century. Nat. Geosci., 5(5), 322-325 (doi: 10.1038/ngeo1450)

Gardelle J, Berthier E, Arnaud Y and Kääb A (2013) Region-wide glacier mass balances over the Pamir-Karakoram-Himalaya during 1999-2011. Cryosphere, 7(4), 1263-1286 (doi: 10.5194/tc-7-1263-2013)

Gardner AS and 15 others (2013) A reconciled estimate of glacier contributions to sea level rise: 2003 to 2009. Science, 340 (6134), 852-857 (doi: 10.1126/science.1234532)

Guo W and 10 others (2015) The second Chinese glacier inventory: data, methods, and results. J. Glaciol., 61(226), 357-372 (doi: 10.3189/2015JoG14J209)

Han H, Wang J, Wei J and Liu S (2010) Backwasting rate on debriscovered Koxkar glacier, Tuomuer mountain, China. J. Glaciol., 56(196), 287-296 (doi: 10.3189/002214310791968430)

Huss M (2013) Density assumptions for converting geodetic glacier volume change to mass change. Cryosphere, 7(3), 877-887 (doi: 10.5194/tc-7-877-2013)

Immerzeel WW, van Beek LPH and Bierkens MFP (2010) Climate change will affect the Asian water towers. Science, 328(5984), 1382-1385 (doi: 10.1126/science.1183188)

IPCC (2013) Climate change 2013: the physical science basis. Contribution of working group I to the fifth assessment report of the intergovernmental panel on climate change. Cambridge University Press, Cambridge, UK and New York, NY, USA, 1535 pp (doi: 10.1017/CBO9781107415324)

Kääb A (2005) Combination of SRTM3 and repeat ASTER data for deriving alpine glacier flow velocities in the Bhutan Himalaya. Remote Sens. Environ., 94(4), 463-474 (doi: 10.1016/j.rse.2004.11.003)

Kääb A, Berthier E, Nuth C, Gardelle J and Arnaud Y (2012) Contrasting patterns of early twenty-first-century glacier mass change in the Himalayas. Nature, 488(7412), 495-498 (doi: 10.1038/nature11324)

Kääb A, Treichler D, Nuth C and Berthier E (2015) Contending estimates of 2003-2008 glacier mass balance over the PamirKarakoram-Himalaya [Brief Communication]. Cryosphere, 9 (2), 557-564 (doi: 10.5194/tc-9-557-2015)

Ke L, Ding X and Song C (2015) Heterogeneous changes of glaciers over the western Kunlun Mountains based on ICESat and Landsat-8 derived glacier inventory. Remote Sens. Environ., 168, 13-23 (doi: 10.1016/j.rse.2015.06.019)

Ke L and 5 others (2016) Compiling a new glacier inventory for southeastern Qinghai-Tibet Plateau from Landsat and PALSAR data. J. Glaciol., 62(233), 579-592 (doi: 10.1017/jog.2016.58) 
Koblet T and 6 others (2010) Reanalysis of multi-temporal aerial images of Storglaciären, Sweden (1959-99) - Part 1: determination of length, area, and volume changes. Cryosphere, 4(3): 333-343 (doi: 10.5194/tc-4-333-2010)

Krieger G and 6 others (2007) TanDEM-X: a satellite formation for high-resolution SAR interferometry. IEEE Trans. Geosci. Remote Sens., 45(11), 3317-3341 (doi: 10.1109/TGRS.2007.900693)

Kubanek J and 5 others (2015) Volumetric change quantification of the 2010 Merapi eruption using TanDEM-X InSAR. Remote Sens. Environ., 164, 16-25 (doi: 10.1016/j.rse.2015.02.027)

Leber D, Holawe F and Häusler H (1995) Climatic classification of the Tibet Autonomous Region using multivariate statistical methods. Geo/ournal, 37, 451-472

Li G and Lin H (2017) Recent decadal glacier mass balances over the Western Nyainqentanglha Mountains and the increase in their melting contribution to Nam Co Lake measured by differential bistatic SAR interferometry. Global Planet. Change, 149, 177190 (doi: 10.1016/j.gloplacha.2016.12.018)

Li J, Zheng B and Yang X (1986) The glaciers of Xizang (Tibet). Science Press, Beijing, Chinese Academy of Sciences, ix +328 pp [In Chinese]

Li X and 9 others (2008) Cryospheric change in China. Global Planet. Change, 62(3-4), 210-218 (doi: 10.1016/j. gloplacha.2008.02.001)

Li L, Yang S, Wang Z, Zhu X and Tang H (2010) Evidence of warming and wetting climate over the Qinghai-Tibet Plateau. Arct. Antarct. Alp. Res., 42(4), 449-457 (doi: 10.1657/1938-424642.4.449)

Li Z, Xing Q, Liu S, Zhou J and Huang L (2012) Monitoring thickness and volume changes of the Dongkemadi ice field on the Qinghai-Tibetan Plateau (1969-2000) using Shuttle Radar Topography Mission and map data. Int. J. Digital Earth, 5(6), 516-532 (doi: 10.1080/17538947.2011.594099)

Li X, Yang T and Ji Q (2014) Study on glacier variations in the Gangrigabu Range. Res. Soil Water Conserv., 21(4), 233-237, In Chinese

Li G, Lin H and YeQ (2018) Heterogeneous decadal glacier downwasting at the Mt. Everest (Qomolangma) from 2000 to similar to 2012 based on multi-baseline bistatic SAR interferometry. Remote Sens. Environ., 206, 336-349 (doi: 10.1016/j.rse.2017.12.032)

Liu S and 6 others (2017) Climate change impacts and risks. The research of climate change impacts and risks on glacier. Science Press, Beijing, [In Chinese]

Loibl D, Lehmkuhl F and Grießinger J (2014) Reconstructing glacier retreat since the Little Ice Age in SE Tibet by glacier mapping and equilibrium line altitude calculation. Geomorphology, 214, 22-39

Maussion F and 5 others (2014) Precipitation seasonality and variability over the Tibetan Plateau as resolved by the High Asia Reanalysis. Journal of Climate, 27, 1910-1927

Mi D and 5 others (2002) Glacier inventory of China XI. the Ganga drainage basin. XII. Indus drainage basin. Xi'an Cartographic Publishing House, Lanzhou Institute of Glaciology and Geocryology, Xi'an, 552 pp [In Chinese]

Molnar P, Boos WR and Battisti DS (2010) Orographic controls on climate and paleoclimate of Asia: thermal and mechanical roles for the Tibetan Plateau. Annu. Rev. Earth Planet. Sci., 38(1), 77-102

Neckel N, Braun A, Kropáček J and Hochschild V (2013) Recent mass balance of the Purogangri ice cap, central Tibetan Plateau, by means of differential X-band SAR interferometry. Cryosphere, 7(5), 1623-1633 (doi: 10.5194/tc-7-1623-2013)

Neckel N, Kropáček J, Bolch T and Hochschild V (2014) Glacier mass changes on the Tibetan Plateau 2003-2009 derived from ICESat laser altimetry measurements. Environ. Res. Lett., 9(1), 014009 (doi: 10.1088/1748-9326/9/1/014009)

Neckel N, Loibl D and Rankl M (2017) Recent slowdown and thinning of debris-covered glaciers in south-eastern Tibet. Earth Planet. Sci. Lett., 464, 95-102 (doi: 10.1016/j.epsl.2017.02.008)

Neelmeijer J, Motagh M and Bookhagen B (2017) High-resolution digital elevation models from single-pass TanDEM-X interferometry over mountainous region: a case study of Inylchek Glacier,
Central Asia. ISPRS J. Photogramm. Remote Sens., 130, 108121 (doi: 10.1016/j.isprsjprs.2017.05.011)

Nuimura T and 12 others (2015) The GAMDAM glacier inventory: a quality-controlled inventory of Asian glaciers. Cryosphere, 9(3), 849-864 (doi: 10.5194/tc-9-849-2015)

Nuth C and Kääb A (2011) Co-registration and bias corrections of satellite elevation data sets for quantifying glacier thickness change. Cryosphere, 5(1), 271-290 (doi: 10.5194/tc-5-2712011)

Oerlemans J (1994) Quantifying global warming from the retreat of glaciers. Science, 264(5156), 243-245 (doi: 10.1126/ science.264.5156.243)

Paul F and 9 others (2009) Recommendations for the compilation of glacier inventory data from digital sources. Ann. Glaciol., 50(53), 119-126 (doi: 10.3189/172756410790595778)

Paul F and 24 others (2015) The glaciers climate change initiative: methods for creating glacier area, elevation change and velocity products. Remote Sens. Environ., 162, 408-426 (doi: 10.1016/j. rse.2013.07.043)

Pellicciotti $F$ and 5 others (2015) Mass-balance changes of the debris-covered glaciers in the Langtang Himal, Nepal, between 1974 and 1999. J. Glaciol., 61(226), 373-386 (doi: 10.3189/ 2015JoG13J237)

Pieczonka T, Bolch T, Wei J and Liu S (2013) Heterogeneous mass loss of glaciers in the Aksu-Tarim catchment (central Tien Shan) revealed by 1976 KH-9 Hexagon and 2009 SPOT-5 stereo imagery. Remote Sens. Environ., 130, 233-244 (doi: 10.1016/j.rse.2012.11.020)

Pu J (2001) Glacier inventory of China IX. The Lancang river. X. The Nujiang river. Xi'an Cartographic Publishing House, Xi'an, 179 pp [In Chinese]

Rabus B, Eineder M, Roth A and Bamler R (2003) The Shuttle radar topography mission: a new class of digital elevation models acquired by spaceborne radar. ISPRS J. Photogram. Remote Sens., 57(4), 241-262 (doi: 10.1016/S0924-2716(02)00124-7)

Racoviteanu AE, Williams MW and Barry RG (2008) Optical remote sensing of glacier characteristics: a review with focus on the Himalaya. Sensors, 8(5), 3355-3383 (doi: 10.3390/s8053355)

Racoviteanu AE, Paul F, Raup BH, Khalsa SJS and Armstrong R (2009) Challenges and recommendations in mapping of glacier parameters from space: results of the 2008 Global Land Ice Measurements from Space (GLIMS) workshop, Boulder, Colorado, USA. Ann. Glaciol., 50(53), 53-69 (doi: 10.3189/ 172756410790595804)

Reid TD and Brock BW (2014) Assessing ice-cliff backwasting and its contribution to total ablation of debris-covered Miage glacier, Mont Blanc massif, Italy. J. Glaciol., 60(219), 3-13 (doi: 10.3189/2013JoG13J045)

Rignot E, Echelmeyer K and Krabill W (2001) Penetration depth of interferometric synthetic-aperture radar signals in snow and ice. Geophys. Res. Lett., 28(18), 3501-3504 (doi: 10.1029/ 2000GL012484)

Sakai A, Nakawo M and Fujita K (2002) Distribution characteristics and energy balance of ice cliffs on debris-covered glaciers, Nepal Himalaya, Arct. Antarct. Alp. Res., 34(1), 12-19 (doi: 10.2307/ 1552503)

Scherler D, Bookhagen B and Strecker MR (2011) Spatially variable response of Himalayan glaciers to climate change affected by debris cover. Nat. Geosci., 4(3), 156-159 (doi: 10.1038/ngeo1068)

Shangguan D and 6 others (2010) Changes in the elevation and extent of two glaciers along the Yanglonghe River, Qilian Shan, China. J. Glaciol., 56(196), 309-317 (doi: 10.3189/ 002214310791968566)

Shangguan D and 10 others (2014) Glacier changes in the Koshi River basin, central Himalaya, from 1976 to 2009, derived from remote-sensing imagery. Ann. Glaciol., 55(66), 61-68 (doi: 10.3189/2014AoG66A057)

Shi Y and Liu S (2000) Estimation on the response of glaciers in China to the global warming in the 21st century. Chin. Sci. Bull., 45(7), 668-672 (doi: 10.1007/BF02886048) 
Shi Y, Huang M and Ren B (1988) An introduction to the glaciers in China. Science Press, Beijing, 243 pp [In Chinese]

Surdyk S (2002) Using microwave brightness temperature to detect short-term surface air temperature changes in Antarctica: an analytical approach. Remote Sens. Environ., 80(2), 256-271 (doi: 10.1016/S0034-4257(01)00308-X)

Vijay S and Braun M (2016) Elevation Change Rates of Glaciers in the Lahaul-Spiti (Western Himalaya, India) during 2000-2012 and 2012-2013. Remote Sens., 8, 1038 (doi: 10.3390/ rs8121038)

Wei J and 6 others (2015) Mass loss from glaciers in the Chinese Altai Mountains between 1959 and 2008 revealed based on historical maps, SRTM, and ASTER images. J. Mt. Sci., 12(2), 330-343 (doi: 10.1007/s11629-014-3175-1)

$\mathrm{Wu} \mathrm{K}$ and 6 others (2016) Glacier change in the western Nyainqentanglha Range, Tibetan Plateau using historical maps and Landsat imagery: 1970-2014. J. Mt. Sci., 13(8), 13581374 (doi: 10.1007/s11629-016-3997-0)

Wu K and 5 others (2018) Recent glacier mass balance and area changes in the Kangri Karpo Mountains from DEMs and glacier inventories. Cryosphere, 12(1), 103-121 (doi: 10.5194/tc-12-103-2018)

Xu J, Liu S, Zhang S, Guo W and Wang J (2013) Recent changes in glacial area and volume on Tuanjiefeng Peak region of Qilian Mountains, China. PLOS ONE, 8(8), e70574 (doi: 10.1371/ journal.pone.0070574)

Yang W and 5 others (2008) Quick ice mass loss and abrupt retreat of the maritime glaciers in the Kangri Karpo Mountains, southeast Tibetan Plateau. Chin. Sci. Bull., 53(16), 2547-2551 (doi: 10.1007/s11434-008-0288-3)

Yang W and 5 others (2010) Characteristics of recent temperate glacier fluctuations in the Parlung Zangbo River basin, southeast Tibetan Plateau. Chin. Sci. Bull., 55(20), 2097-2102 (doi: 10.1007/s11434-010-3214-4)

Yang W and 5 others (2013) Mass balance of a maritime glacier on the southeast Tibetan Plateau and its climatic sensitivity. J. Geophys. Res. Atmos., 118(17), 9579-9594 (doi: 10.1002/ jgrd.50760)

Yang K and 5 others (2014) Recent climate changes over the Tibetan Plateau and their impacts on energy and water cycle: a review.
Global Planet. Change, 112, 79-91 (doi: 10.1016/j. gloplacha.2013.12.001)

Yao T, Ren J and Xu B (2008) Map of glaciers and lakes on the Tibetan Plateau and adjoining regions. (Scale: 1:2,000,000) Xi'an Cartographic Publishing House, Lanzhou Institute of Glaciology and Geocryology, Xi'an [In Chinese]

Yao T and 14 others (2012) Different glacier status with atmospheric circulations in Tibetan Plateau and surroundings. Nat. Clim. Change, 2(9), 663-667 (doi: 10.1038/nclimate1580)

Ye Q and 8 others (2015) Glacier mass changes in Rongbuk catchment on Mt. Qomolangma from 1974 to 2006 based on topographic maps and ALOS PRISM data. J. Hydrol., 530, 273-280 (doi: 10.1016/j.jhydrol.2015.09.014)

You Q and 6 others (2010) Relationship between temperature trend magnitude, elevation and mean temperature in the Tibetan Plateau from homogenized surface stations and reanalysis data. Global Planet. Change, 71(1-2), 124-133 (doi: 10.1016/j. gloplacha.2010.01.020)

Zhang Y, Fujita K, Liu S, Liu Q and Nuimura T (2011) Distribution of debris thickness and its effect on ice melt at Hailuogou glacier, southeastern Tibetan Plateau, using in situ surveys and ASTER imagery. J. Glaciol., 57(206), 1147-1157 (doi: 10.3189/ 002214311798843331)

Zhang Z and 6 others (2016) Mass change of glaciers in Muztag AtaKongur Tagh, eastern Pamir, China from 1971/76 to 2013/14 as derived from remote sensing data. PLOS ONE, 11(1), e0147327 (doi: 10.1371/journal.pone.0147327)

Zhao Y and Zhu J (2015) Assessing quality of grid daily precipitation datasets in China in recent 50 years. Plateau Meteorology, 34(1), 50-58 (doi: 10.7522/j.issn.1000-0534.2013.0014) [In Chinese]

Zhou Y, Li Z, Li J, Zhao R and Ding X (2018) Glacier mass balance in the Qinghai-Tibet Plateau and its surroundings from the mid1970s to 2000 based on Hexagon KH-9 and SRTM DEMs. Remote Sens. Environ., 210, 96-112 (doi: 10.1016/j. rse.2018.03.020)

Zwally HJ and 11 others (2011) Greenland ice sheet mass balance: distribution of increased mass loss with climate warming; 200307 versus 1992-2002. J. Glaciol., 57(201), 88-102 (doi: 10.3189/ $002214311795306682)$ 